\title{
Biogeochemical processes and geotechnical applications: progress, opportunities and challenges
}

\author{
J. T. DEJONG ${ }^{1}$, K. SOGA ${ }^{2}$, E. KAVAZANJIAN ${ }^{3}$, S. BURNS ${ }^{4}$, L. A. VAN PAASSEN ${ }^{5}$, A. AL QABANY $^{2}$,

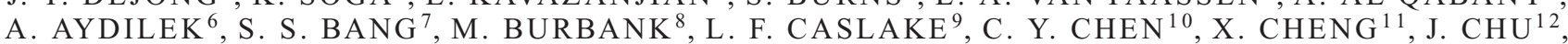 \\ S. CIURLI ${ }^{13}$, A. ESNAULT-FILET ${ }^{14}$, S. FAURIEL $^{15}$, N. HAMDAN ${ }^{16}$, T. HATA $^{17}$, Y. INAGAKI ${ }^{18}$,

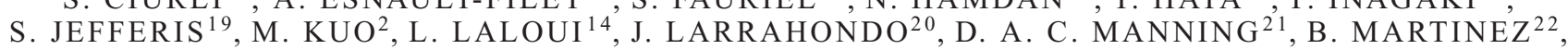 \\ B. M. MONTOYA ${ }^{23}$, D. C. NELSON ${ }^{24}$, A. PALOMINO ${ }^{25}$, P. RENFORTH ${ }^{26}$, J. C. SANTAMARINA ${ }^{4}$, \\ E. A. SEAGREN ${ }^{27}$, B. TANYU ${ }^{28}$, M. TSESARSKY ${ }^{29}$ and T. WEAVER ${ }^{30}$
}

\begin{abstract}
Consideration of soil as a living ecosystem offers the potential for innovative and sustainable solutions to geotechnical problems. This is a new paradigm for many in geotechnical engineering. Realising the potential of this paradigm requires a multidisciplinary approach that embraces biology and geochemistry to develop techniques for beneficial ground modification. This paper assesses the progress, opportunities, and challenges in this emerging field. Biomediated geochemical processes, which consist of a geochemical reaction regulated by subsurface microbiology, currently being explored include mineral precipitation, gas generation, biofilm formation and biopolymer generation. For each of these processes, subsurface microbial processes are employed to create an environment conducive to the desired geochemical reactions among the minerals, organic matter, pore fluids, and gases that constitute soil. Geotechnical applications currently being explored include cementation of sands to enhance bearing capacity and liquefaction resistance, sequestration of carbon, soil erosion control, groundwater flow control, and remediation of soil and groundwater impacted by metals and radionuclides. Challenges in biomediated ground modification include upscaling processes from the laboratory to the field, in situ monitoring of reactions, reaction products and properties, developing integrated biogeochemical and geotechnical models, management of treatment by-products, establishing the durability and longevity/reversibility of the process, and education of engineers and researchers.
\end{abstract}

KEYWORDS: chemical properties; environmental engineering; ground improvement; remediation; soil stabilisation

Manuscript received 2 March 2012; revised manuscript accepted 23 October 2012.

Discussion on this paper closes on 1 August 2013, for further details see p. ii.

${ }^{1}$ Department of Civil and Environmental Engineering, University of California, Davis, CA, USA.

2 Department of Engineering, University of Cambridge, Cambridge, UK.

${ }^{3}$ School of Sustainable Engineering and the Built Environment, Arizona State University, Phoenix, AZ, USA.

${ }^{4}$ School of Civil and Environmental Engineering, Georgia Institute of Technology, Atlanta, GA, USA.

${ }^{5}$ Department of Geoscience and Engineering, Delft University of Technology, The Netherlands.

${ }^{6}$ Department ofCivil and Environmental Engineering, University of Maryland, College Park, MD, USA.

${ }^{7}$ Department of Chemical and Biological Engineering, South Dakota School of Mines and Technology, Rapid City, SD, USA.

${ }^{8}$ Environmental Biotechnology Institute, University of Idaho, Moscow, ID, USA.

${ }^{9}$ Department of Biology, Lafayette College, Easton, PA, USA.

${ }^{10}$ Department of Earth and Environmental Sciences, National Chung Cheng University, Taiwan.

${ }^{11}$ Department of Civil Engineering, Tsinghua University, Beijing, China.

12 Department of Civil, Construction and Environmental Engineering, Iowa State University, Ames, IA, USA

${ }^{13}$ Department of Agro-Environmental Science and Technology, University of Bologna, Bologna, Italy.

${ }^{14}$ Research \& Development Department, Soletanche Bachy, Rueil
Malmaison, France.

${ }^{15}$ Laboratory for Soil Mechanics, Ecole Polytechnique Fédérale de Lausanne (EPFL), Lausanne, Switzerland.

${ }^{16}$ Department of Civil, Environmental and Sustainable Engineering, Arizona State University, Tempe, AZ, USA.

${ }^{17}$ Department of Civil Engineering, Nagano National College of Technology, Nagano, Japan.

${ }^{18}$ Geology and Geotechnical Engineering Research Group, Public Works Institute, Japan.

${ }^{19}$ Environmental Geotechnics Ltd and Department of Engineering Science, University of Oxford, Banbury, UK.

${ }^{20}$ INGETEC S. A., Bogota, Columbia.

${ }^{21}$ School of Civil Engineering \& Geosciences, Newcastle University, Newcastle upon Tyne, UK.

${ }^{22}$ Geosyntec Consultants, Oakland, CA, USA.

${ }^{23}$ Department of Civil, Construction, and Environmental Engineering, North Carolina State University, Raleigh, NC, USA.

${ }^{24}$ Department of Microbiology, University of California, Davis, CA, USA.

${ }^{25}$ Department of Civil and Environmental Engineering, University of Tennessee, Knoxville, TN, USA.

${ }^{26}$ Department of Earth Sciences, University of Oxford, Oxford, UK.

${ }^{27}$ Department of Civil and Environmental Engineering, Michigan Technological University, Houghton, MI, USA.

${ }^{28}$ Department of Civil, Environmental, and Infrastructure Engineering, George Mason University, Fairfax, VA, USA.

${ }^{29}$ Department of Structural Engineering and Department of Geological and Environmental Sciences, Ben Gurion University of the Negev, Beer-Sheva, Israel.

${ }^{30}$ Office of Research, Nuclear Regulatory Commission, USA 


\section{INTRODUCTION}

Biology in the evolution of geotechnical engineering

The field of geotechnical engineering has advanced steadily throughout history; the durability of several ancient geotechnical systems (e.g. Egyptian dams and canals, Greek strip and raft foundations, and Roman bridges along the Appian Way) testifies to a working knowledge of geotechnics by their creators. However, formal initiation of the discipline may be attributed to Coulomb's definitive work on earth pressures in the 1770s. Numerous advances in mechanics and water flow followed Coulomb's work, including Darcy's law (Darcy, 1857), Boussinesq stress distribution (1871), Rankine earth pressure theory (1875), Mohr's circle of strain (1885), Reynolds volumetric behaviour (1885), and more. Karl Terzaghi's work, from the 1920s onwards (e.g. Terzaghi, 1924), revolutionised the discipline by developing the principle of effective stress and analyses for the bearing capacity of foundations and consolidation of soils. Later work by Gibson on analytical techniques (see the first issue of Géotechnique), by Taylor (1948) on dilation and interlocking, by Roscoe et al. (1958) and Schofield \& Wroth (1968) on plasticity and critical state, and by many others since then and through to the present day, have continued the development of mechanics concepts and analysis methods for geotechnical systems.

The natural origins of soils, and hence their variability and changes in properties over time, result in engineering mechanics alone being insufficient to address many practical problems. The geologic origin of a soil, its depositional mode and environment, thixotropic processes, and other post-depositional phenomena must often be considered. Early on (e.g. Terzaghi, 1955), the importance of considering these formational and time-dependent processes was recognised and addressed through the field of geology. Work by Mitchell (e.g. Mitchell, 1975) and others in the second half of the 20th century recognised the critically important role of chemistry in the behaviour of fine-grained soils, and how macro-scale performance depends directly on micro- (or nano-) scale conditions. For example, some ground improvement methods specifically target chemical changes in the clay fabric to stabilise soils for construction (e.g. pozzolanic changes).

Harnessing of biological processes in soils promises to be the next transformative practice in geotechnical engineering. For many years, the influence of plant roots on slope stability has been recognised and exploited (e.g. Gray \& Sotir, 1996). There is now the opportunity to exploit many chemical processes that are mediated by biology. Although ignored for centuries with respect to geotechnical behaviour, microbes are ubiquitous in soils at surprisingly high concentrations, almost regardless of saturation, mineralogy, $\mathrm{pH}$, and other environmental factors. Near the ground surface, more than $10^{12}$ microbes exist per kilogram of soil (Mitchell \& Santamarina, 2005). At depths typical in geotechnical systems (e.g. 2 to $30 \mathrm{~m}$ ), the microbial population decreases to about $10^{11}$ to $10^{6}$ microorganisms per kilogram respectively (Whitman et al., 1998) (for context, about $10^{14}$ bacteria exist in the typical human body; Berg, 1996). Living organisms at other length scales are also present. For example, worms at larger length $(\mathrm{cm})$ scales recompact soil, create preferential drainage conditions, and otherwise impact on soil characteristics, and spores at smaller length scales $(<1 \mu \mathrm{m})$ can be transported into smaller pore spaces.

A permanent biological presence (microbes have been active geotechnical engineers for $3+$ billion years, much longer than the 0.0002 billion years for humans; Kohnhauser, 2007) in soil provides opportunities for geotechnical engineering to consider soil as a living ecosystem rather than as an inert construction material. Biological activity in soil can potentially explain observations in some case histories that have troubled experts (Mitchell \& Santamarina, 2005) and provides the opportunity to manipulate soil using natural or stimulated processes (as expanded upon herein).

\section{Emergence of bio-soils as a subdiscipline}

One of the first explicit discussions of the application of biological processes in geotechnical engineering was presented by Mitchell \& Santamarina (2005), and in parallel it was identified as an important research topic by the US National Research Council (NRC, 2006) for the 21st century. The first international workshop on biogeotechnical engineering in 2007 facilitated interdisciplinary discussions and prioritisation of research topics in this emerging field (DeJong et al., 2007). Research advanced quickly, with a bio-geo-civil-engineering conference in 2008, and several dedicated sessions at national and international conferences, additional papers assessing the potential of the field (Ivanov \& Chu, 2008; Kavazanjian \& Karatas, 2008; Ivanov, 2010; Seagren \& Aydilek, 2010; DeJong et al., 2011; Hata et al., 2011), and more than 100 technical conference and journal papers dedicated to this topic since. Research programmes on biogeotechnical engineering are currently active in more than 15 countries around the world.

The Second International Workshop on Bio-Soils Engineering and Interactions, funded by the US National Science Foundation, was held in September 2011 at the University of Cambridge. This workshop assembled 35 of the leading researchers in the field, and provided an opportunity to assess progress to date, identify the primary challenges and opportunities that lie ahead, and develop strategies for advancing this rapidly developing field. This paper presents the outcomes of the workshop, along with a perspective on the possible role of biological processes in geotechnical engineering, including examples of their application and a discussion of salient issues.

\section{POTENTIAL OF BIOLOGY TO MODIFY ENGINEERING PROPERTIES OF SOILS}

Length scales of biological processes

The processes by which biology can modify the engineering properties of soil depend on the length scale of organisms, both in absolute dimension and relative to the particle size. Multicellular organisms, ranging from plant roots down to insects and invertebrates (e.g. ants, worms), alter soils through both mechanical and biological processes. For example, ants are effective at soil grading, densification, and creating preferential flow paths (macropores); they also adapt and optimise their efforts considering capillarity forces at particle contacts (Espinoza \& Santamarina, 2010). Similarly, mucous excretion from worms can strengthen soil along tunnelling paths, and help bind (geotechnically strong) faecal pellets to such an extent that the cone penetration test (CPT) measures the strength increase (Kuo, 2011).

Unicellular microbial organisms in soil consist primarily of bacteria and archaea (see Woese et al., 1990, for definitions of terms), which typically range in diameter from 0.5 to $3 \mu \mathrm{m}$, and have morphologies that are typically spherical (coccus) or cylindrical; the latter may be straight (rods), curved (vibrio), or corkscrew shaped (spirilla). These are present in soil either through entrapment during deposition (the typical mode in fine-grained sediments offshore; Rebata-Landa \& Santamarina, 2006) or through migration through pore space via hydraulic flow transport or selfmotility. Geometric compatibility between bacteria and archaea and the pore space (pore throats to be specific) 
dictates mobility (Mitchell \& Santamarina, 2005; DeJong et al., 2010; Phadnis \& Santamarina, 2012) and survivability (Rebata-Landa \& Santamarina, 2006).

Unicellular activity, in general, does not affect soil properties directly. Rather, it is how biological activity locally exploits geochemical processes, which in turn affect soil properties. Microbe activity creates 'microniche' conditions surrounding individual cells that critically alter when, where, and at what rate geochemical processes occur. A given geochemical process can often occur in the absence of biological activity, and indeed, for it to occur as a microbial process, it must be viable in the absence of biological activity, although the rate may be exceedingly slow (i.e. bioprocesses are often regarded as biocatalysis). However, doing so may result in widely distributed reactions, resulting, for example, in precipitation in the pore fluid that is subsequently transported outside the targeted treatment zone.

The ability of microbes to regulate processes (depending on the specific process utilised) often stems from the unicells containing the enzyme(s) critical to the geochemical reaction. The location of the enzyme, usually within the cell membrane or within the membrane-bound cytoplasm, regulates (through diffusion or active transport) the rate at which the reaction can occur. Increased enzymatic activity within a given cell or an increased number of cells both increase the bulk reaction rate. Although not widely explored to date, it may also be possible to use free enzymes (a non-biological approach) to improve soil properties in applications where the treatment time is relatively brief (e.g. dust suppression; Bang et al., 2011).

\section{Methods of application: processes and products}

Development of a biomediated soil improvement technique requires an application strategy. The two primary strategies - bioaugmentation (where the required microbes are injected into the soil) and biostimulation (where natural microbes are stimulated) - build on bioremediation techniques developed over the last $30+$ years. While the former has been the primary strategy used to date in exploring geotechnical applications, the geoenvironmental field is increasingly using biostimulation. Bioaugmentation is generally considered less favourable than biostimulation, owing to the introduction of exogenous (non-native) microbes, in some cases the permissions required, the increased costs, the practical difficulty of uniform application in the subsurface due to filtration of microbes (akin to filter design intended to protect clay cores of dams), and the potential for die-off or dormancy if the environment is not favourable for their proliferation. Biostimulation is generally preferable, owing to the stimulation and growth of native microbes, which are adapted to the subsurface environment, and to the reduction in permission difficulties. However, many challenges exist in applying biostimulation, including obtaining uniform treatment across a site, and accommodating the increased time associated with stimulation and growth. A compromise between these two approaches may be bioaugmentation at a low concentration followed by stimulation in situ, or 'microdosing' (Martinez, 2012).

Geochemical processes regulated through biostimulation or bioaugmentation often result in multiple products. The primary product is typically the one that is designed to be the desired outcome (e.g. calcite precipitation to bind soil particles together). In addition, there are often additional 'by-products' generated by the geochemical process (e.g. ammonium ions). The generation, transport and fate of these by-products must be addressed, often as a waste, although in some cases they may be repurposed for other applications (e.g. ammonium for fertilisation of plants).
Potential improvements to engineering properties with biogeochemical processes

Biomediated geochemical processes have the potential to modify physical properties (density, gradation, porosity, saturation), conduction properties (hydraulic, electrical, thermal), mechanical properties (stiffness, dilation, compressibility, swell/shrink, cohesion, cementation, friction angle, erodibility, and soil-water characteristic curve), and chemical composition (buffering, reactivity, cation exchange capacity) of soils. This may be conceptualised by considering how different biogeochemical processes may influence an assemblage of sand grains and/or an aggregation of clay platelets.

Biomineralisation processes that precipitate inorganic solids (including microbially induced calcite precipitation, or MICP) can clearly have a mechanical effect: for example, reduction in pore space, brittle cementation at particle contacts, increased fines in the pore space, and increased stiffness. These effects will predictably result in reduced hydraulic conductivity, increased small-strain stiffness, increased large-strain strength, and increased dilative behaviour.

Biofilm formation, and the production of other extracellular polymeric substances (EPS), are additional biogeochemical processes that can impact on soil behaviour. These processes generate organic solids that occupy a portion of the pore space with a soft, ductile, elastomeric-like material that reduces pore size, reduces rearrangement of particles during soil deformation, and increases ductility. These changes can reduce hydraulic conductivity, and perhaps reduce rapid strain-softening during undrained shearing. However, property changes due to biofilm and EPS production may be lost, and thus be applicable only for short-term ground modification, as these living systems must be continuously nourished or their engineering performance may become unreliable.

Biogas generation from denitrification or other biogeochemical processes may enable long-term reduction in the degree of saturation of a soil. Reduction in the degree of saturation increases pore space compressibility, and may thereby reduce excess pore pressure build-up during cyclic loading, mitigating earthquake-induced liquefaction potential in some soils.

Other processes that have been identified, but are currently less developed, include algal and fungal growth for nearsurface soil stabilisation, bacteria and worms for methane oxidation, biopolymers for drilling applications, organic slurries for hydraulic control, and silicate precipitation.

\section{RESEARCH ACTIVITY AND APPLICATIONS}

Research activity in biogeotechnical engineering to date has investigated many of the above potential processes, with a significant portion of activity focused on biomediated cementation via calcite precipitation. The following examples highlight the extent to which soil properties can be modified or improved by biogeochemical processes. These examples are not comprehensive, with additional references provided.

\section{Microbially induced calcite precipitation}

Microbially induced calcite precipitation, or MICP, has been the primary focus of research in biogeotechnical engineering to date. In MICP, the creation of calcium carbonate (calcite) occurs as a consequence of microbial metabolic activity (Stocks-Fischer et al., 1999; Ramakrishnan et al., 2001). Calcite precipitation may be achieved by many different processes (DeJong et al., 2010), including urea hydrolysis (Benini et al., 1999; Ciurli et al., 1999); 
denitrification (Karatas et al., 2008; Van Paassen et al., 2010a; Hamdan et al., 2011b); sulphate reduction, inducing dolomite precipitation (Warthmann et al., 2000); and iron reduction, inducing ankerite and other mixed mineral precipitation (Roden et al., 2002; Weaver et al., 2011). Enzymatic hydrolysis of urea by microbes is the most energy efficient of these processes (DeJong et al., 2010), and urease activity is found in a wide range of microorganisms and plants (Bachmeier et al., 2002). Bacillus pasteurii (American Type Culture Collection 6453), which was recently reclassified as Sporosarcina pasteurii (ATCC 11859), an alkalophilic bacterium with a highly active urease enzyme (Ferris et al., 1996), has been used in laboratory studies where bioaugmentation has been performed to produce calcite precipitation (Mortensen et al., 2011). More recently, biostimulation of native microbes has reportedly been successful (Burbank et al., 2011, 2012a), and the influence of competing microbe species/processes has been explored (Gat et al., 2011). Limited studies have also explored precipitation of other minerals (e.g. Chu et al., 2011; Weaver et al., 2011).

Research has provided insights into MICP from micrometre- to metre-length scales (Fig. 1). Microscopy techniques show that the calcite structure varies with treatment formulation (Al Qabany et al., 2012), cementation occurs preferentially at particle contacts (Chou et al., 2008; Martinez \& DeJong, 2009), calcite precipitation occurs directly on or around individual microbes and their aggregates, and cementation breakage during shearing occurs within the calcite crystals (DeJong et al., 2011). Laboratory-scale element tests have shown substantial $\left(>10^{3} \times\right)$ increases in strength (DeJong et al., 2006; Whiffin et al., 2007; Van Paassen et al., 2009; Chu et al., 2011, 2013; Al Qabany \& Soga, 2013), decreases in hydraulic conductivity greater than two orders of magnitude (Al Qabany, 2011; Rusu et al., 2011; Martinez et al., 2013), increases in small-strain stiff- ness by three orders of magnitude (DeJong et al., 2006; Van Paassen et al., 2010b; Van Paassen, 2011; Esnault-Filet et al., 2012), and an increase in dilative tendencies (Chou et al., 2011; Mortensen \& DeJong, 2011; Tagliaferri et al., 2011). Even after cementation degrades owing to shearing, the reduction in pore space (or increase in solids density) due to the precipitated calcite alters the behaviour of the material. Re-establishment of properties following MICP degradation from shearing can be rapid and efficient (Montoya, 2012). Geophysical methods (shear wave velocity in particular) are effective for real-time monitoring of the cementation process, as the precipitated calcite stiffens particle-particle contacts (Al Qabany et al., 2011; Montoya et al., 2012; Weil et al., 2012).

One-dimensional column, two-dimensional flow and threedimensional model tests have enabled enquiry into treatment uniformity, formulation optimisation, and self-equilibrating ability, as well as demonstration of conceptual ideas about property improvement due to MICP (DeJong et al., 2009; Martinez \& DeJong, 2009; Van Paassen, 2009; Van Paassen et al., 2009; Inagaki et al., 2011a; Tobler et al., 2012; Martinez et al., 2013) (Fig. 1). One-dimensional column experiments have shown pulsed flow injection and flow reversal to increase uniformity, lowering the molar ratio of urea to calcium to reduce by-product formation, and geophysical seismic measurement to spatially monitor improvement (Martinez, 2012). Two-dimensional models of field treatment patterns have explored the efficacy of bioaugmentation compared with biostimulation, and linkages between microbial distribution, ureolysis activity, shear wave velocity and total precipitated calcite (Al Qabany, 2011; Martinez, 2012). Scale model tests have demonstrated the effectiveness of MICP in reducing wind- and water-induced erosion (Bang et al., 2011), improving resistance to liquefaction (Inagaki et al., 2011b; Montoya et al., 2013), creating impermeable crusts

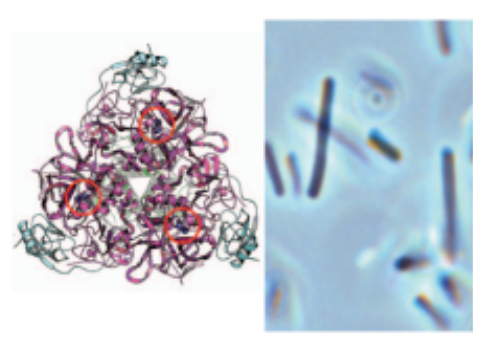

(a)

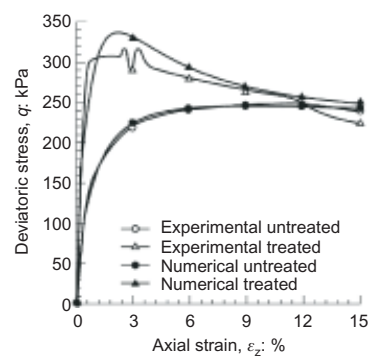

(h)

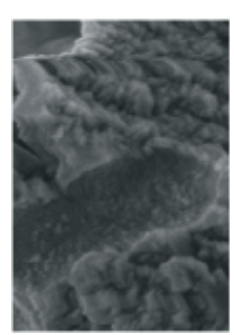

(c)

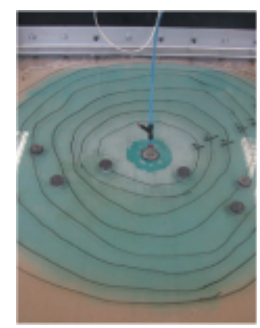

(j)

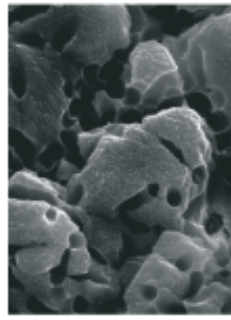

(d)

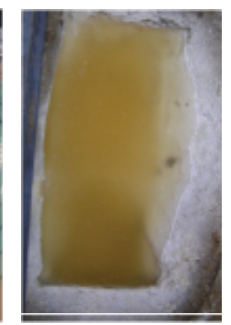

(k)

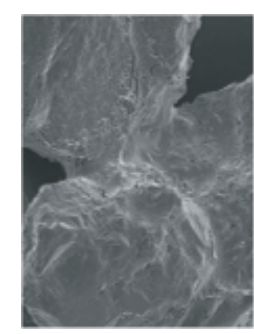

(e)

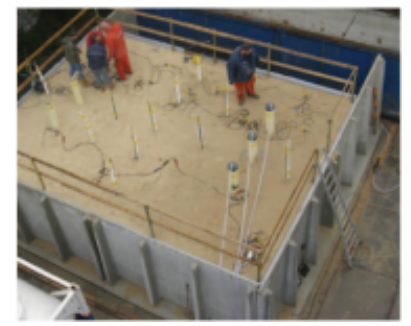

(I)

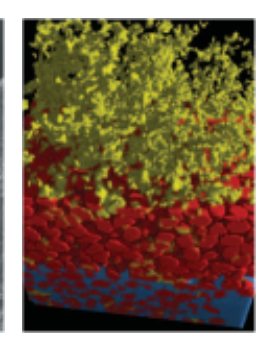

(f)

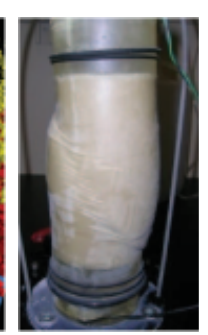

(g)

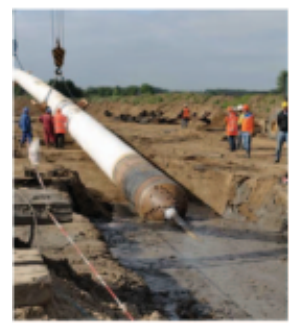

(m)

$\mathrm{cm}$

$\mathrm{dm}$

m

km

Fig. 1. Overview of upscaling of MICP: (a) urease enzyme structure housed within microbes (Benini et al., 1999); (b) Sporosarcina pasteuri microbe (image supplied by DeJong); (c) bacterial impression within precipitated calcite (Martinez \& DeJong, 2009); (d) structure of precipitated calcite (Day et al., 2003); (e) MICP-cemented sand grains (Chou et al., 2008); (f) CT scan of MICP-cemented sand (image supplied by DeJong); (g) MICP-cemented triaxial specimen (Mortensen et al., 2011); (h) modelling of MICP triaxial compression test (Fauriel, 2012); (i) 1D column tests (Martinez, 2012); (j) radial flow treatments (Al Qabany, 2011); (k) MICP impermeable skin for retention basin (Stabnikov et al., 2011); (l) MICP treatment of $100 \mathrm{~m}^{3}$ sand (Van Paassen et al., $2010 \mathrm{~b}$; Esnault-Filet et al., 2012); (m) field trial 
for catchment facilities (Stabnikov et al., 2011; Chu et al., 2012), healing/stabilising cracks in concrete and masonry (Ramachandran et al., 2001; Bang et al., 2010; Yang et al., 2011), treating waste (Chu et al., 2009), immobilising heavy metals (Fujita et al., 2004, 2008, 2010; Hamdan et al., 2011a; Li et al., 2011), and performing shallow carbon sequestration (Manning, 2008; Renforth et al., 2009, 2011; Washbourne et al., 2012). MICP has also been shown to increase cone tip resistance (Burbank et al., 2012b).

Modelling of MICP requires coupling of biological, chemical, hydrological, and mechanical processes. Modelling efforts have generally focused either on prediction of biogeochemical processes (Barkouki et al., 2011; Fauriel \& Laloui, 2011b, 2012; Laloui \& Fauriel, 2011; Martinez et al., 2011; Van Wijngaarden et al., 2011, 2012; Martinez, 2012) and calcite distribution, or on prediction of the mechanical behaviour of biocemented soils (Fauriel \& Laloui, 2011a; Fauriel, 2012). Models to date have captured and predicted biogeochemical processes, provided first-order predictions of precipitated calcite distributions, and captured the mechanical behaviour of MICP-treated sand (Fig. 1(h)).

As discussed later in the section on field applications, two field trials using MICP have been performed to date.

\section{Biofilm formation}

Biofilms form when microorganisms adhere to a surface and excrete EPS as part of their metabolism. This 'slimy' EPS enhances further attachment of more microorganisms and other particles, thereby forming a biofilm that can affect the physical properties of soils (Fig. 2(a); Banagan et al., 2010). Close to the surface in riverine and marine environments, biofilms play an important role in trapping and stabilising sediments, and increasing the resistance to erosion (Stal, 2010). In the subsurface, it has been shown already that the growth of biofilms can reduce hydraulic conductivity (Slichter, 1905), a process referred to as bioclogging. Much of the research on bioclogging is focused on preventing and/ or removing the clogging material (Howsam, 1990), for example by flushing with formaldehyde, in order to restore or maintain the functionality of wells or drains (Baveye et al., 1998). However, some researchers have found that biofilm formation in soil could also be advantageous (e.g. Mitchell et al., 2009). For example, Talsma \& van der Lelij (1976) observed that water losses from rice fields were limited, owing to bacterial clogging. Attempts have been made to use bioclogging to decrease hydraulic conductivity in situ beneath and within dams and levees, to reduce infiltration from ponds, to reduce leakage at landfills, to plug high hydraulic conductivity layers surrounding oil bearing layers, and to control groundwater migration with subsurface barriers (Fig. 2(b); Seki et al., 1998; James et al., 2000; Lambert et al., 2010).

\section{Biogas generation}

Biological activity in the subsurface is frequently accompanied by the development of discrete gas bubbles in otherwise saturated environments. A variety of gases can be produced by microbial processes (e.g. carbon dioxide, hydrogen, methane and nitrogen), with both the organism and the oxidative/reductive environment of the pore fluid influencing the ultimate products of the reaction. For example, aerobic microbes (obligate or facultative) use oxygen as the terminal electron acceptor during the process of microbial respiration. Typically, an organic molecule is used as the carbon and energy source, and the products resulting from the reaction include water and carbon dioxide. By contrast, anaerobic respiration by methanogenic archaea occurs in the absence of oxygen, and results in the production of methane and

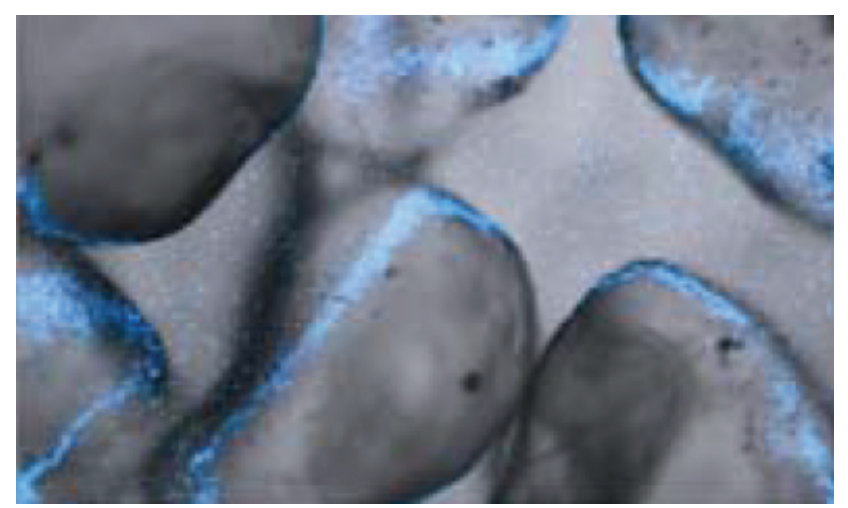

(a)

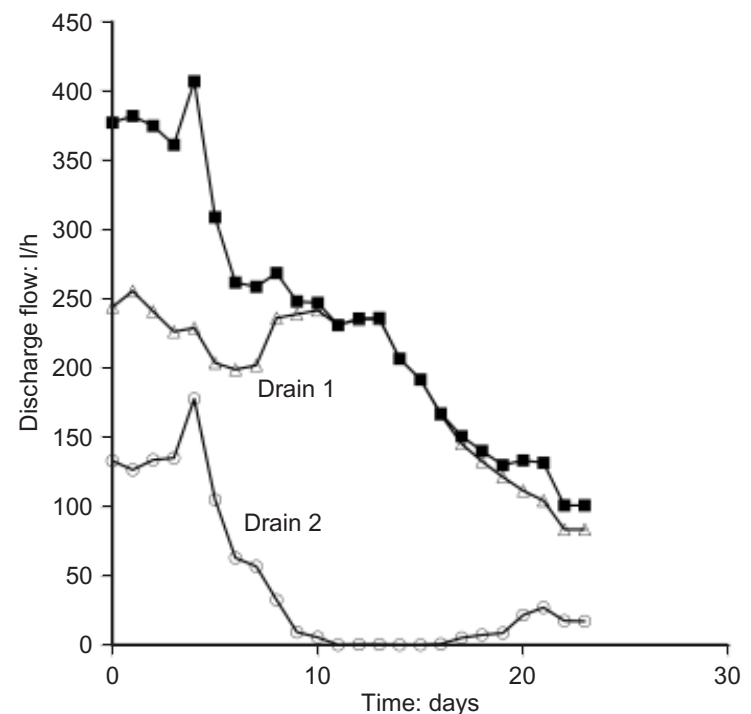

(b)

Fig. 2. Example results of biofilm treatment for permeability reduction; (a) laser confocal fluorescence microscopy image of biofilm-coated sand grains; (b) field data showing reduction in seepage flow in a dam following biofilm hydraulic conductivity reduction treatment (Blauw et al., 2009; used by permission)

often carbon dioxide (i.e. part of the carbon is oxidised to carbon dioxide and part is reduced to methane). The process uses part of the carbon, as opposed to oxygen, as the terminal electron acceptor. Respiratory denitrification occurs through the reduction of nitrate, producing nitrogen and carbon dioxide gas as the end products of the reaction in environments that have high ratios of nitrate to carbon. Numerous laboratory studies have demonstrated the feasibility of producing microbially generated discrete gas bubbles at the bench scale, with a review of the processes given in Rebata-Landa \& Santamarina (2012), and shaking-table tests provided by He et al. (2013). In practical terms, the presence of gas bubbles within an otherwise saturated soil results in a decrease in the measured P-wave velocity; this decrease is transient in coarse-grained soils, but not in finegrained soils that can trap the generated gas bubbles (Fig. 3(a); Rebata-Landa \& Santamarina, 2012). Even small reductions in the level of saturation of a soil are known to significantly reduce a soil's susceptibility to liquefaction (Fig. 3(b); e.g. Sherif et al., 1977; Chaney, 1978; Yoshimi et al., 1989; Ishihara et al., 2001; Pietruszczk et al., 2003).

\section{Biopolymers and EPS}

Both in situ and ex situ applications of biopolymers for soil improvement have been explored. Biopolymers mixed with soils have been shown to reduce hydraulic conductivity 


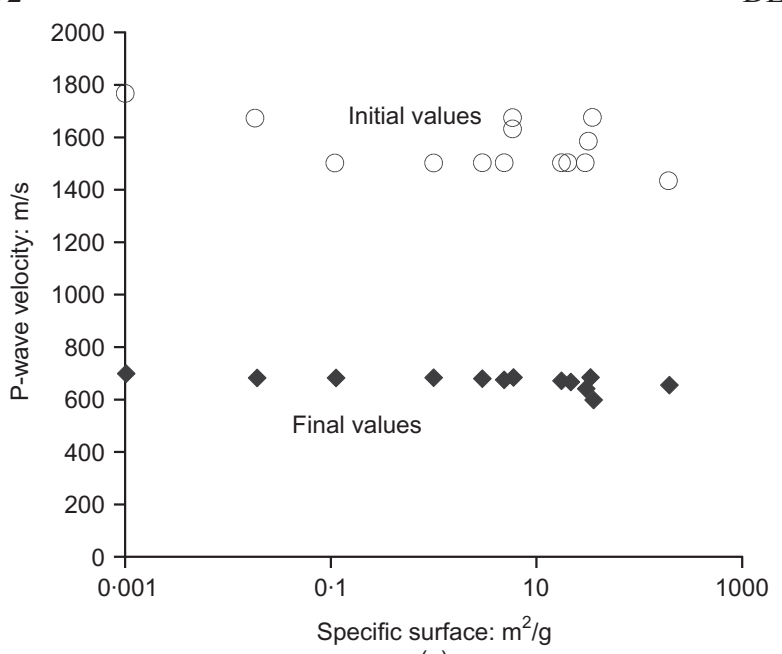

(a)

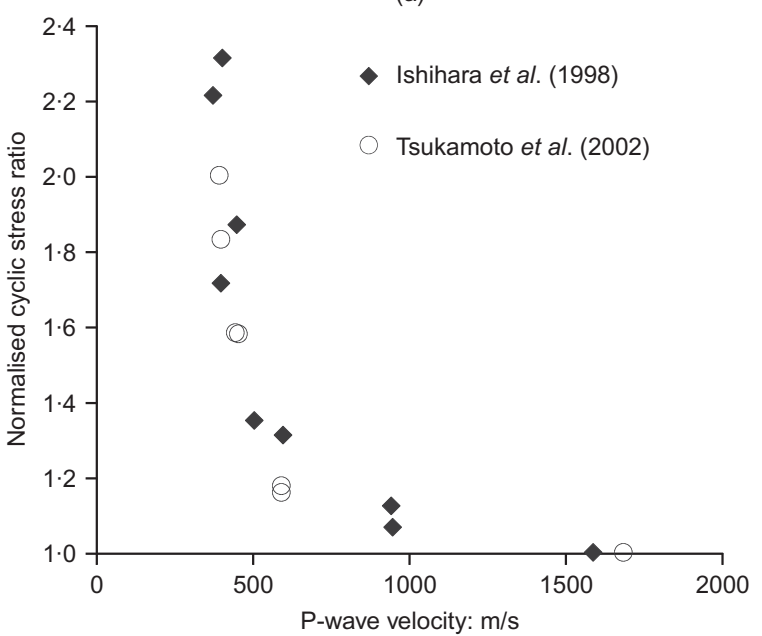

(b)

Fig. 3. Reduction in saturation monitored by $\mathbf{P}$-wave velocity in initially saturated sand due to nitrogen gas generation via biogeochemical treatment process of denitrification: (a) P-wave velocities pre- and post-treatment, with consistent performance across a broad range of specific surfaces (grain sizes); (b) published relationship between $\mathbf{P}$-wave velocity (corollary to saturation) and cyclic strength, indicating that reduction in saturation (via denitrification) could increase liquefaction resistance (RebataLanda \& Santamarina, 2012; used by permission)

and increase shear strength (Kavazanjian et al., 2009; Nugent et al., 2010). Martinez et al. (2011) showed that mixing silt with $0 \cdot 3 \%$ (by weight) xanthan gum, a commercially available biopolymer, can reduce saturated hydraulic conductivity by two orders of magnitude (down to $\sim 10^{-6} \mathrm{~cm} / \mathrm{s}$ ) and increase the drained shear strength by up to $30 \%$. The observed reduction in hydraulic conductivity is a function of soil grading and the applied hydraulic gradient (Jefferis, personal communication, 2012). Biopolymers are used in biodegradable drilling muds owing to their propensity for bioplugging (Hamed \& Belhadri, 2009). They have also been used as temporary excavation support fluids to create permeable reactive barriers for groundwater remediation, with biopolymer degradation accelerated by the introduction of a high-pH 'enzyme breaker' after placement of the permeable reactive material in an open trench (Sivavec et al., 2003). Khachatoorian et al. (2003) observed permeability decreases in less than 2 weeks in sand treated with a biopolymer slurry. Some investigators have explored increasing soil shear strength in situ by biopolymer generation (e.g. Cabalar \& Canakci, 2005). However, most investigations of applications of in situ biopolymer growth and EPS generation have focused on reduction in hydraulic conductivity to form hydraulic barriers (e.g. Wu et al., 1997; Bonala \& Reddi, 1998; Seki et al., 1998). Furthermore, there are many case histories of clogging of filters in dams, landfills and water treatment plants caused by the growth of biofilms (Cullimore, 1990; Ivanov \& Chu, 2008). For example, in October 1985 an investigation of subsurface drain clogging at the Ergo Tailings Dam (ETD) in South Africa, after only 6 months' service, revealed that the geotextile drain filter was clogged by the growth of arsenic-resistant microorganisms (Legge et al., 1985).

\section{Mechanical processing by marine worms}

Many deep ocean clays are subject to thousands of cycles of biological activity that transform virgin material into processed material. Burrowing invertebrates (worms), through the process of bioturbation, digest sediment that has fallen through the water column to the seabed. They are one example of a biological agent that has been active for millennia. During feeding, the ingested sediment, containing clay, organic matter, foraminifera, diatoms, shell fragments and other detritus, is processed in the gut, removing material of nutritional value. The remaining material is expelled by the worm's hind gut (Barnes et al., 1988) in the form of faecal pellets that are compacted and bound by mucus (see Fig. 4(a)). These resulting pellets are significantly stronger than the material initially ingested, and have undrained shear strengths of between $1 \mathrm{kPa}$ and $12 \mathrm{kPa}$ (Kuo \& Bolton, 2012). If sufficiently numerous, these pellets can produce measurable increases in bulk sediment strength within the top few metres of deep ocean clay sediments. The sedimentation rate in many of these locations may only be of the order of $0.1 \mathrm{~mm}$ per year (Kuo, 2011). Worms, however, may digest material at a rate of $0.75 \mathrm{~mm}$ each year if hypothetically located at a plan spacing of $1 \mathrm{~m}$ (Gingras et al., 2008). It is therefore plausible that, over the sediment's lifetime, worms are biologically engineering all material settling on the seabed into robust pellets. These pellets' collective presence (in some cases $20-60 \%$ of total sediment by dry mass; Kuo, 2011) can be measured as a crust-like feature during in situ strength testing with conventional tools, including ball and T-bar fullflow penetrometers (see Fig. 4(b), following Kuo \& Bolton, 2011). Because of their proximity to the seabed, faecal pellets are of significant engineering interest in the design of offshore pipelines and shallow foundations.

\section{Shallow carbon fixation through plant roots}

It may be possible to design a carbon sequestration function in soils through exploiting and extending natural processes of pedogenic carbonate function. Widely observed in natural soils, pedogenic carbonate minerals form as a consequence of reaction between plant root exudates and calcium derived from silicate mineral weathering. It has recently been shown that this process also occurs in urban soils, as a consequence of reaction between root exudates and calcium derived from the dissolution or weathering of cement-based construction materials (Manning, 2008; Renforth et al., 2009, 2011; Washbourne et al., 2012). Plants exude $10-30 \%$ of carbon captured from the atmosphere by photosynthesis through their roots and associated mycorrhizal fungal associations (Kuzyakov \& Domanski, 2000; Taylor et al., 2009). Root tissue compounds are released into the soil as exudates (Jones et al., 2009), which are complex materials composed of polysaccharides, proteins, phospholipids, cells that detach from roots, and other compounds. Respired carbon dioxide and organic acid anions that naturally decompose and can react with calcium-rich silicates 

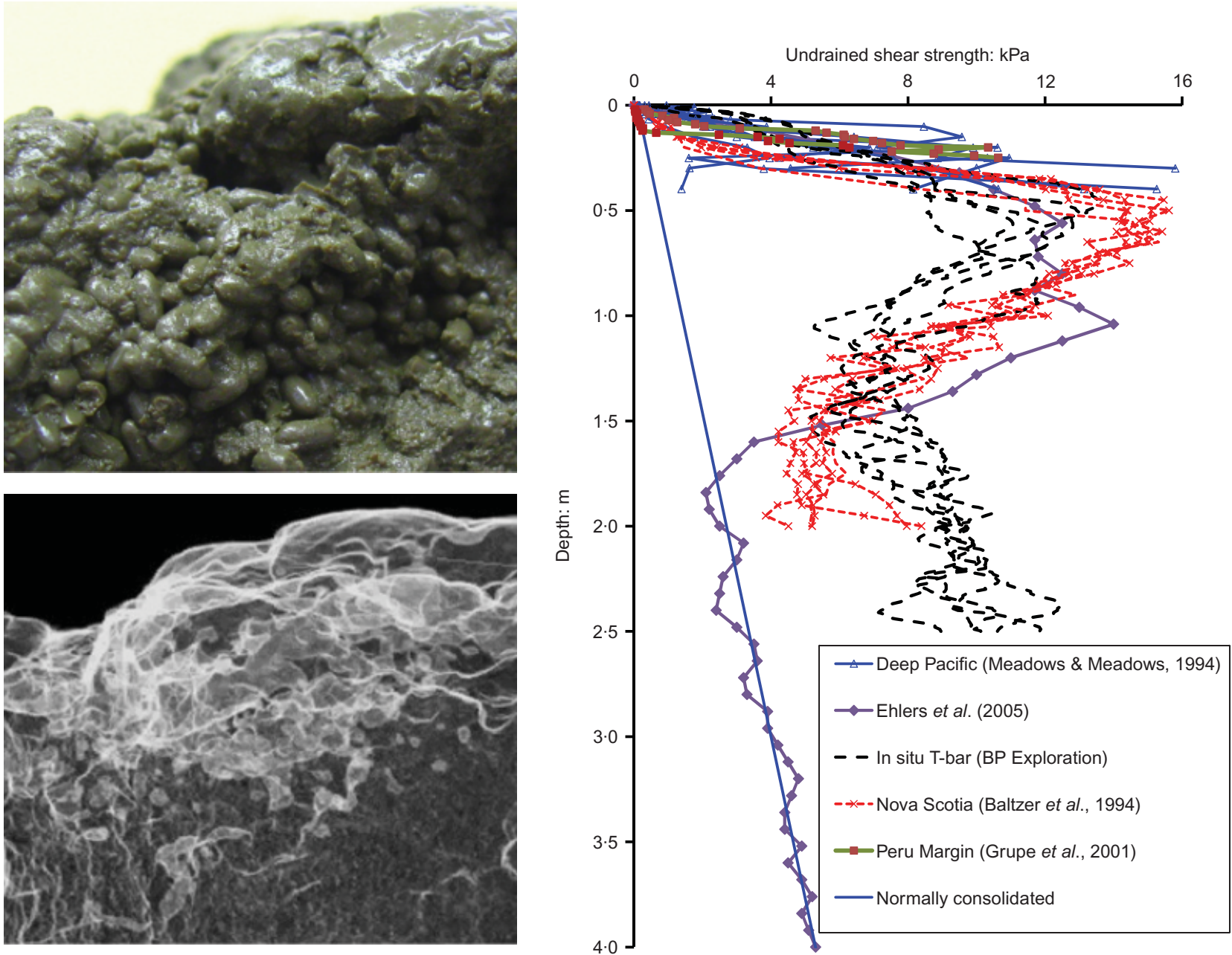

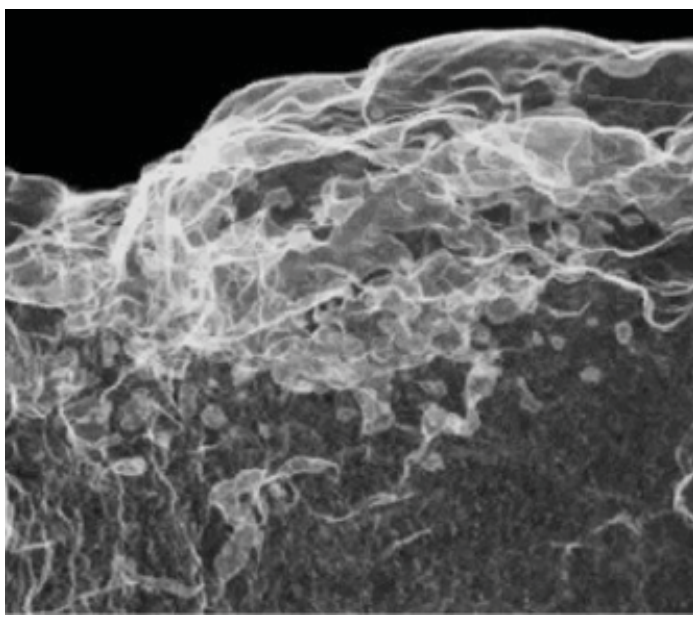

(a)

(b)

Fig. 4. Natural example of bioturbation by multicellular organisms such as worms, etc.: (a) image and SEM of faecal pellets from nearsurface offshore fine-grained sediments (note micro- and macropores evident in SEM) (Kuo et al., 2010; used by permission); (b) clearly detectable crystal layer, formation is attributed largely to bioturbation (Baltzer et al., 1994; Meadows \& Meadows, 1994; Grupe et al., 2001; Ehlers et al., 2005)

within soils are of particular interest. Manning (2008), Renforth et al. (2009, 2011) and others (Sanderson, 2008) have recorded that this process occurs naturally in soils at brownfield sites and can be very rapid (Washbourne et al., 2012). As summarised in Fig. 5, the resequestration of carbon emitted during cement/lime production into the subsurface may be possible through the admixing of recycled concrete and furnace slag into soils used for non-food crops and urban revegetation (Manning, 2008).

\section{FIELD APPLICATIONS}

\section{Completed/ongoing field trials}

To date, only a few field trials have been performed in which microbes have actively been used to either increase the strength and stiffness of soils by microbially induced carbonate precipitation or reduce the hydraulic conductivity through biofilm formation, although such processes will have been occurring naturally for millennia.

Two field trials using MICP are reported in the literature, the first using a bioaugmentation strategy and the second stimulating the indigenous species to induce precipitation. Contractor Visser \& Smit Hanab applied a MICP treatment for gravel stabilisation to enable horizontal directional drilling (HDD) for a gas pipeline in the Netherlands in 2010 (Fig. 6; from Van Paassen, 2011). The treatment was applied to a $1000 \mathrm{~m}^{3}$ volume at depths varying between 3 and $20 \mathrm{~m}$ below the surface. The treatment involved injection of a $200 \mathrm{~m}^{3}$ bacterial suspension that was cultivated in the laboratory, two injections of $300-600 \mathrm{~m}^{3}$ of reagent solution containing urea and calcium chloride, and extraction of groundwater until electrical conductivity and ammonium concentrations returned to background values. MICP was monitored using electrical resistivity, groundwater sampling and physical sampling for calcite content measurements, with varying degrees of success. Overall, the MICP treatment was a success, as HDD was possible without instability in the loose gravel deposit.

A second set of MICP field trials using biostimulation to evaluate the capability of co-precipitation of heavy metals (strontium-90) with calcium carbonate (to immobilise the heavy metals) was initiated at the Vadose Zone Research Park (VZRP) at the Idaho National Laboratory (INL), and is ongoing at the US Department of Energy site in Rifle, Colorado, USA (Fujita et al., 2010). These trials have employed injection of dissolved molasses and urea in the target treatment zone (calcium available in groundwater), with contemporaneous withdrawal of groundwater from a well several metres away from the injection point. At the Rifle site the well-to-well cycle is closed by reinjection of withdrawn water. To date, native microbes have been successfully stimulated at both sites, and calcite precipitation appears to be in progress. The rate of precipitation is slower than in the bioaugmentation application in the Netherlands 


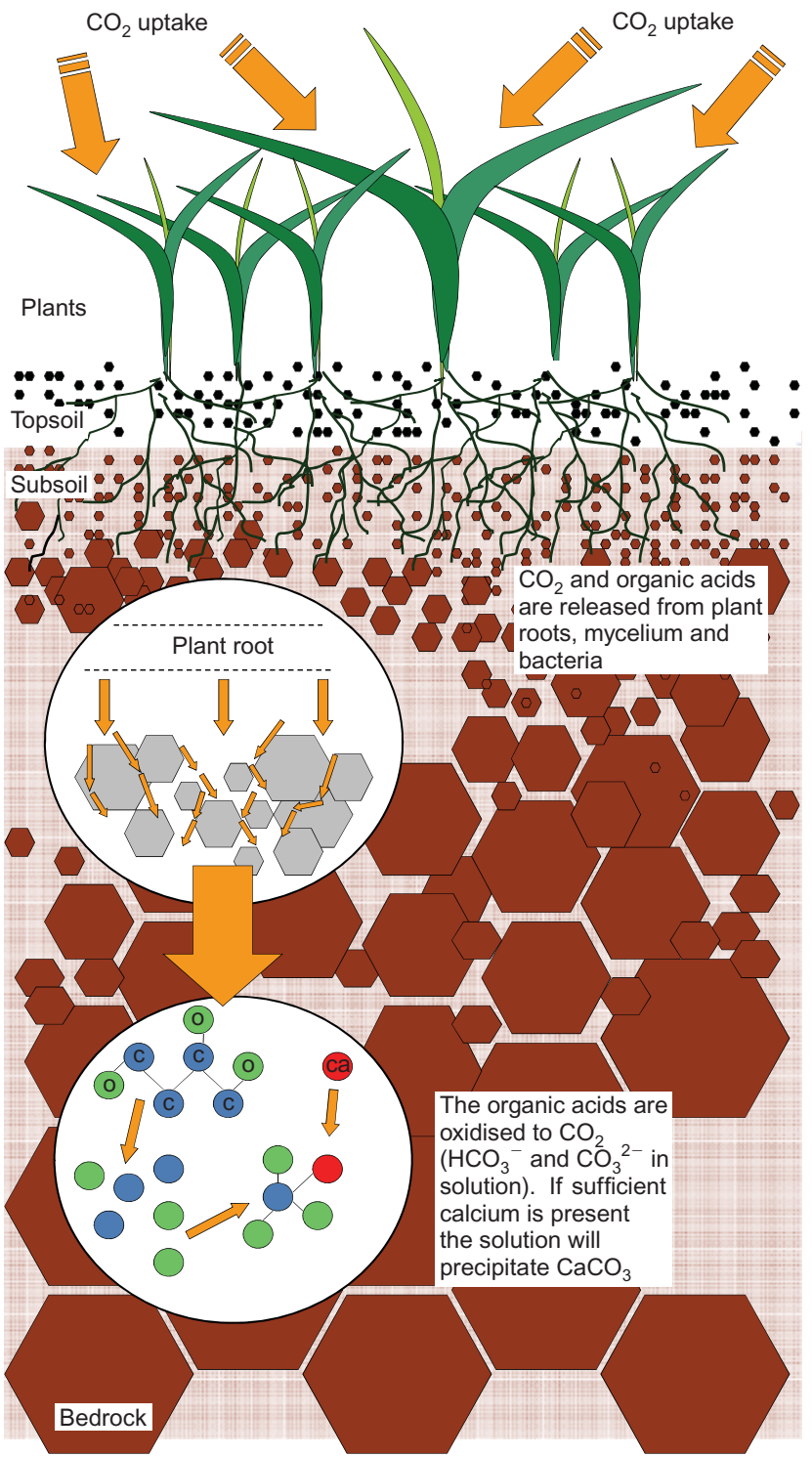

Fig. 5. Overview of biomediated (plants) near-surface carbon sequestration observed and documented by Manning \& Renforth (described in Manning, 2008)

described above, but is nonetheless advancing at a sufficient rate for the project requirements.

Successful field trials of bioclogging have also been reported in the Netherlands and Austria, with the objective of reducing leakage through water-retaining constructions (Van Meurs et al., 2006; Blauw et al., 2009). In Austria, nutrient solutions were injected through a screen of injection wells in the crest of a 'leaking' dike along the Danube river in Greifenstein (Blauw et al., 2009; Lambert et al., 2010). Injection was performed in two stages. During and following the first injection phase (November-December), no significant flow reduction was observed in downstream drains. However, during the second treatment phase (July-August), a significant reduction in discharge rate was observed (Fig. 2(b)). The measurement of a significant reduction in redox potential indicated biochemical activity in the treated area. The actual mechanism behind the reduction in permeability is not yet fully understood (Blauw et al., 2009). Whether it is the biofilm itself that clogs the pores, or some trapped particles in the biofilm, or perhaps the biogeochemical conversions that stimulate attachment, detachment or precipitation of particles that can reduce the hydraulic conductivity still needs to be resolved.
In southern Ontario, Canada, researchers (Lambert et al., 2010) have also been successful in reducing hydraulic conductivity in a fractured dolostone formation in order to block the flow of contaminated groundwater. Nutrient solutions (molasses) were injected several times into the ground to stimulate bioclogging. Geochemical measurements indicated that microbial growth and a significant increase in microbial diversity were observed. The longevity of the biofilm appeared to be limited, as the hydraulic conductivity returned to its initial condition 230 days after the nutrient injections had stopped.

\section{Challenges for field implementation}

The process of upscaling to the field, following experimental and modelling research at the element and bench scales, raises the following challenges that must be considered and addressed.

Characterisation of subsurface heterogeneity. The treatment of $100+\mathrm{m}^{3}$ of naturally deposited soil requires characterisation of both soil and microbial spatial distributions at different scales. Similar to chemical injection methods, preferential flow - and therefore initial treatment - will occur within zones of larger pore space (hydraulic conductivity). Recent work indicates that MICP may be 'self-equilibrating' to some extent, as the precipitated calcite does reduce conductivity; when the level of reduction is sufficient in fine-grained soils, treatment may redirect towards untreated (and relatively higher conductivity) zones (Martinez, 2012). The spatial microbial distribution does not necessarily map with soil particle variations, and hence targeted delivery of microbes to the improvement area may be required. From a practical standpoint, the primary interest is the bulk reactivity level in the soil (i.e. the rate at which a chemical reaction can occur in a soil volume) required for a given biogeochemical process; the exact microbial species, their absolute population, and other environmental factors are not critically important. Instead it is the bulk activity level that the biota (all microbes) provide for a specific process that is the key factor. For ureolysis-based MICP, the critical bulk activity is the rate at which urea is hydrolysed. The bulk ureolysis rate can be tested by injecting and monitoring the spatial degradation of aqueous urea temporally (Martinez et al., 2013).

Treatment schemes for uniform improvement. The first task in developing a treatment scheme is to identify the level of improvement required. Laboratory test results enable identification of an ideal improvement threshold (akin to grouting methods), but the actual application level of treatment is often higher in the field because of allowances for spatial variability. To minimise the additional application level that must be achieved in the field, the treatment scheme must be optimised for treatment uniformity. The treatment scheme selected depends largely on whether the nutrients and/or microbes can be delivered relatively uniformly across the treatment zone through injection; this uniformity is directly a function of solution viscosity and density as well as microbe size relative to soil pore throat size and of course, critically, the soil uniformity. In situ treatment is typically possible in gravels, sands and silty sands. Uniform treatment using biogeochemical processes can utilise technologies from the ground improvement, geoenvironmental remediation and oil production industries. For example, grouting methods, including injection/extraction well patterns, point injection sources and treatment solution mixing equipment, were successfully used in the MICP field trial in the Netherlands (Van Paassen, 2011). 


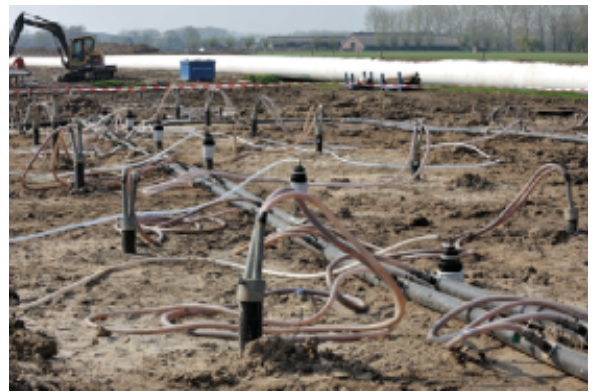

(a)

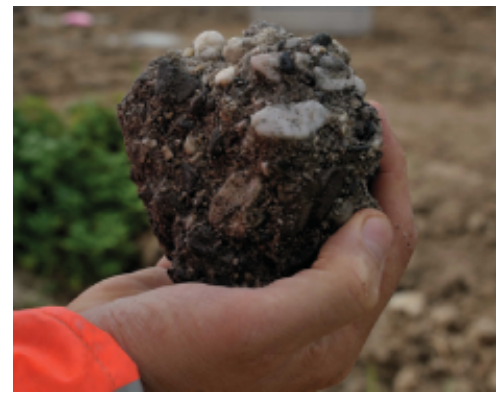

(b)

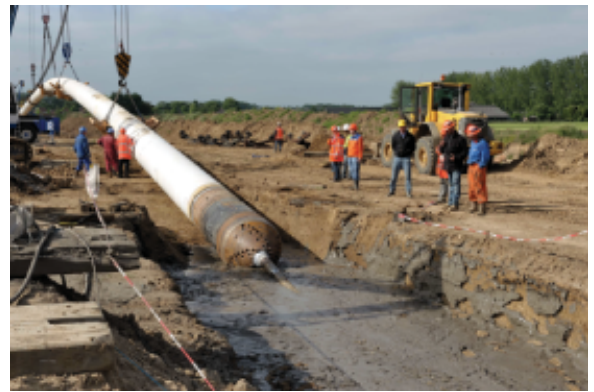

(c)

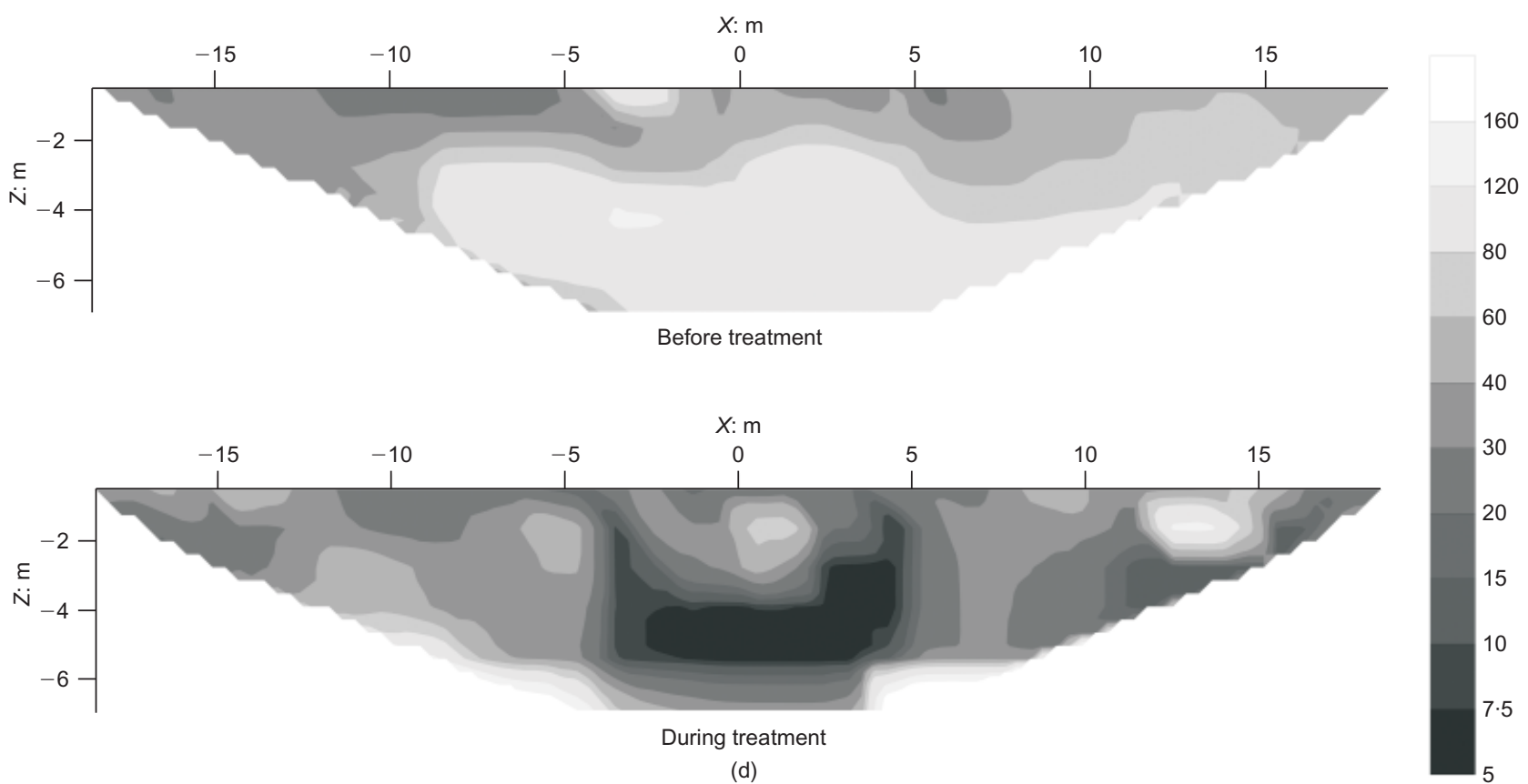

Fig. 6. Overview of MICP field trial for stabilisation of loose gravel for horizontal directional drilling (project described by Van Paassen (2011)): (a) repeating well pattern; (b) sample of MICP-stabilised gravel; (c) pipeline installation after horizontal directional drilling (provided by Visser \& Smit Hanab); (d) resistivity mapping before and during treatment (provided by Deltares)

A more localised approach using a five-spot injection/ extraction well pattern with pulsed injections following geoenvironmental and oil production techniques has also been successful at both field and model scales (Fujita et al., 2010; Martinez, 2012). If treatment of fine-grained soils such as clay is desired, mechanical mixing, either in situ or ex situ, may be necessary. These methods have been marginally successful in the laboratory, and implementation using conventional ground improvement equipment such as deep soil mixing tools may be problematic, as rapid pressure drops and high shearing stresses may cause lysing (bursting) of cells. Other variables that must also be considered but are not yet fully understood include single versus multiple phase injections schemes, continuous versus pulsed injection, surficial flooding versus deep injection, and short, high-concentration treatments versus slow, low-concentration treatments.

Construction, operation and maintenance. Nearly all research performed to date has focused on implementation of the biogeochemical processes for improvement/modification of the soil properties. However, realising the treatment in situ is only the first stage of development of an application. As discussed above, biogeochemical processes may have byproducts (such as ammonia) that must be managed. Byproduct management requires consideration of the fate and transport of the by-products, as well as verification that the treatment does not degrade with time owing to geotechnical mechanical loading (e.g. an earthquake), or chemical (e.g. dissolution by carbon-dioxide-rich waters) or biochemical processes that may change the rate of chemical processes. Use of the observational method may be appropriate for this technology. If degradation over time is of concern, then retreatment, or 'healing', of the biogeochemical treatment might be a possible solution, although inducing additional costs and implementation constraints (Montoya, 2012).

Service life. Selection of an appropriate biogeochemical treatment for a specific application requires compatibility of its permanence and durability with service life requirements. MICP-treated sand is expected to be stable for more than 50 years, provided alkaline conditions persist (DeJong et al., 2009), as its longevity is expected to be consistent with that of natural calcite-rich geomaterials. A $50+$ year time frame is compatible with the expected service life of many structures, and occasional retreatment can be applied to extend this service life. On the other hand, biofilms require a continuous nutrient source, and therefore may be more suitable for shortterm hydraulic control applications (Cunningham et al., 1997). In either case, a risk assessment with respect to treatment longevity, including assessment of the groundwater-precipitate interaction and a performance-monitoring programme, may be appropriate. 
Performance monitoring. Central to any improvement method - biogeochemical or conventional - is monitoring during treatment to verify that the required distribution and magnitude of improvement are realised, and, after treatment, to verify that the improvement level remains adequate throughout the service life. This typically requires a rigorous quality assurance/quality control (QA/QC) process during construction by the contractor to verify the 'certainty of execution' (an issue for conventional ground improvement techniques). The QA/QC programme would be likely to include a verification testing programme that specifies the number of samples obtained, tests to be performed on samples, field tracer tests, monitoring of reactants and products during treatment, and/or geophysical measurements. In addition, a reduced, but continuous, level of monitoring by the owner/operator throughout the service life (perhaps bimonthly to yearly) is likely to be required. Post-improvement monitoring may also become a regulatory compliance issue similar to that for geoenvironmental remediation projects.

Modelling of biogeochemical treatment processes. The interdisciplinary nature of biomediated geochemical processes requires integration of the biological and chemical components within the hydraulic and mechanical modelling techniques already established in geotechnical finite-element and finite-difference modelling codes, as well as the development of new constitutive models for the behaviour of bio-treated soil. Current models can predict final spatial MICP calcite distribution, and model the mechanical element behaviour of MICP-treated sand. Issues that remain include the integration of relevant biogeochemical reaction networks, small-scale biochemical processes (i.e. microbial growth, enzymatic rates, gas generation, etc.), local changes in porosity (and hydraulic conductivity) and saturation, modelling of degradative processes in treated soils, and more. Modelling of spatial variability (microbes versus soil particles) and identifying the appropriate transition from discrete to continuum scales (i.e. microbes and soil particle versus bulk reaction rate and porosity) will be particularly challenging, as the biogeochemical processes occur at the micrometre length scale.

Sustainability: life cycle analysis and embodied energy. One of the attractive attributes of biogeotechnology is the utilisation of natural, biogeochemical processes to improve soil. These processes have the potential for significant reduction in embodied energy and carbon emissions, relative to conventional ground improvement methods such as soil stabilisation using Portland cement. Sustainability analyses to date are limited, and challenges regarding the definition of system boundaries and the service life period must still be resolved. However, with respect to MICP, soil improvement with calcite production requires less carbon than cement stabilisation, but additional analysis is required to study the energy required for manufacturing of the urea and calcium chloride, for injection of the improvement media into the ground, and for treatment of by-products.

Cost. The cost of biogeochemical treatment schemes will be dependent on the process used, and on details of the specific field project. With very limited field applications, the actual costs of the various improvement processes are largely unknown. Studies and cost estimates to date vary widely, owing to suboptimised treatment schemes being implemented to date. Ivanov \& Chu (2008) estimated material costs for MICP (e.g. urea, calcium) of about US $\$ 5 / \mathrm{m}^{3}$ (range from $0 \cdot 5$ to 9), and total costs of MICP treatment (materials, equipment, and installation) in saturated soils range from US\$25-75/ $\mathrm{m}^{3}$ (DeJong, personal communication, 2011) to about US $\$ 500 / \mathrm{m}^{3}$ (Esnault-Filet, personal communication, 2011). Recent work by Cheng \& Cord-Ruwisch (2012) found that materials and costs may be reduced through more efficient cementation. While their estimate encompasses a wide range, the lower half of this range is competitive with many conventional ground improvement techniques, such as deep soil mixing, jet grouting and chemical grouting. It also shows that, in common with many other ground treatment processes, the major cost is in delivery. If processes can be developed that enable biotreatment to be delivered more economically, then strong potential exists.

\section{Feasibility for different applications}

Realistically, biogeochemical-based soil improvement technologies will never replace all conventional ground improvement techniques. However, the following general attributes make these technologies potentially favourable in many instances: they are based on natural processes; they often require less energy; they are deployable beneath and around existing structures, and are non-disruptive to those structures; and they may enable improvement over larger distances, owing to their low viscosity and injection pressure requirements. Thanks to these attributes, biogeochemical soil improvement technologies may provide opportunities to address broad societal priorities, such as climate change, energy, food, shelter, infrastructure, urbanisation, sustainability, waste management, safety, water availability and economic stability.

Considering the general attributes of biogeochemical processes, the challenges for implementation in the field, and society's needs, the applications with the highest likelihood of success will, in general, require simple implementation, provide a unique answer to a problem, have competitive costs, and have a potential for rapid take-up by industry and society. Within this context, 24 different biogeochemical applications were identified and evaluated in a qualitative manner against the criteria of cost, implementation, probability of success, and social acceptance as part of the 2012 Workshop activities. The applications and their approximate 'ranking' against these criteria are presented in Table 1.

The applications that seem most feasible in the near term include erosion control, environmental remediation, dust control, improvement of rural roads, surface carbon dioxide sequestration, repair of sandstone structures, and solidification of fly ash. All of these applications still require further development, but they all represent problems for which current solutions are insufficient. Longer-term 'blue sky' applications include the creation of underground space (for storage or transport), deep carbon dioxide sequestration, stabilisation of sink holes, and control of underground hydraulic flow. In all these cases, the current capital-costdriven construction industry essentially forces consideration of a new biogeochemical technique, because current best practices are insufficient. However, if capital costs are merely competitive with current industry methods, the triedand-true established methods in industry that have decades of experience will often be preferred.

\section{CLOSURE: RESEARCH AND DEVELOPMENT NEEDS}

The rapid development of biomediated soil improvement methods over the last decade has generated exciting advances in geotechnology, from the micro scale up through successful field-scale application. Experimental, analytical and numerical techniques from the fields of geotechnical 
Table 1. Evaluation of application alternatives and their potential, considering implementation feasibility, probability of success, cost/ viability, and social acceptance

\begin{tabular}{|c|c|c|c|c|c|}
\hline Application & $\begin{array}{c}\text { Implementation } \\
\text { Easy: } 5 \\
\text { Difficult: } 1\end{array}$ & $\begin{array}{c}\text { Probability of } \\
\text { success } \\
\text { High: } 5 \\
\text { Low: } 1\end{array}$ & $\begin{array}{l}\text { Cost/viability } \\
\text { Economic: } 5 \\
\text { Expensive: } 1\end{array}$ & $\begin{array}{l}\text { Societal } \\
\text { acceptance } \\
\text { High: } 5 \\
\text { Low: } 1\end{array}$ & $\begin{array}{c}\text { Total score out } \\
\text { of } 20\end{array}$ \\
\hline $\begin{array}{l}\text { Structural repair } \\
\text { Erosion control } \\
\text { Co-precipitation/immobilisation of contaminants } \\
\text { Dust mitigation } \\
\text { Ground improvement for rural roads } \\
\text { Shallow carbon sequestration } \\
\text { Leak management } \\
\text { Rehabilitation of ancient monuments } \\
\text { Ground improvement for urban road subgrading } \\
\text { Soil liquefaction mitigation (MICP) } \\
\text { Ground improvement for ash ponds } \\
\text { Recycling/reuse of dredging materials } \\
\text { Soil liquefaction mitigation (biogas) } \\
\text { Enhanced water/oil/gas recovery } \\
\text { De-desertification } \\
\text { Sediment weakening by fluidisation } \\
\text { Underground creation (pipeline) } \\
\text { Stabilisation of sinkholes } \\
\text { Landfills as new energy resource } \\
\text { Construction products (bricks) using soil-biocementation } \\
\text { Water storage } \\
\text { De-swelling of clays } \\
\text { Deep carbon sequestration } \\
\text { Underground creation (tunnel) }\end{array}$ & $\begin{array}{l}5 \\
4 \\
5 \\
4 \\
5 \\
5 \\
4 \\
3 \\
5 \\
3 \\
1 \\
3 \\
3 \\
1 \\
1 \\
3 \\
3 \\
1 \\
3 \\
3\end{array}$ & $\begin{array}{l}5 \\
5 \\
4 \\
5 \\
5 \\
5 \\
3 \\
3 \\
3 \\
3 \\
3 \\
5 \\
4 \\
4 \\
2 \\
3 \\
3 \\
5 \\
5 \\
2 \\
4 \\
3 \\
3\end{array}$ & $\begin{array}{l}3 \\
4 \\
4 \\
4 \\
4 \\
3 \\
4 \\
4 \\
4 \\
5 \\
5 \\
3 \\
3 \\
3 \\
4 \\
3 \\
3 \\
3 \\
3 \\
1 \\
3\end{array}$ & $\begin{array}{l}5 \\
5 \\
5 \\
5 \\
4 \\
5 \\
5 \\
5 \\
4 \\
3 \\
5 \\
5 \\
3 \\
5 \\
5 \\
3 \\
3 \\
5 \\
2 \\
3 \\
2 \\
4\end{array}$ & $\begin{array}{r}18 \\
18 \\
18 \\
18 \\
17 \\
17 \\
16 \\
16 \\
15 \\
14 \\
14 \\
13 \\
12 \\
12 \\
12 \\
11 \\
11 \\
11 \\
10 \\
10 \\
9 \\
7 \\
6 \\
5\end{array}$ \\
\hline
\end{tabular}

engineering, geoenvironmental engineering, microbiology and geochemistry have been integrated, making this a truly interdisciplinary field. MICP has evidently been the primary focus of efforts to employ biogeotechnical ground improvement technology to date. The focus on MICP is simultaneously encouraging, as this focus has resulted in a successful field-scale trial within a decade of its initial development in the laboratory, and unsatisfying, as there are probably so many other biogeochemical processes that have yet to be identified and/or be subject to intensive research. Advances within MICP include the development of biostimulation and bioaugmentation techniques, quantified improvements in stiffness, strength, conductivity, etc., developed geophysical methods for real-time monitoring, optimised treatment in one-dimensional and two-dimensional models, demonstrated improvement to liquefaction resistance through centrifuge modelling, the development and verification of bio-geochemical-mechanical numerical models, field-scale implementation, and much more. This has clearly validated and demonstrated the potential influence of biological processes on engineering soil properties, and on opportunities for geotechnical field applications.

Many alternative biogeochemical processes have received little attention compared with MICP, and there are undoubtedly many such processes that have yet to be discovered. Promising results of biogas via denitrification, biofilm formation, biocementation through alternative geochemical pathways, and the generation of biopolymers and biofilms for strength enhancement and permeability reduction all show potential, but require further development.

Monitoring techniques to verify treatment success, and to monitor durability and performance over the project's service life, have been identified as an important consideration. However, implementation and interpretation of various monitoring techniques in field trials are required to develop reliable monitoring methods. While appropriate monitoring techniques will vary, depending on the biogeochemical pro- cess selected, geophysical methods have a high potential for indirectly mapping the effect that a treatment process may have on engineering soil properties. The permanence, or longevity, of a treatment method must match or exceed the required service life; this is a challenging criterion to satisfy, as physical experiments to date extend at most 2 years (although modelling results indicate a potential service live of 50 years or more).

While not addressed explicitly herein, a new workforce is required to embrace and help realise the development of biogeochemical treatment methods in the geotechnical community. To develop this workforce, education and training must include the fundamentals of biology and chemistry, producing engineers who can intelligibly converse and engage with experts in these areas on interdisciplinary teams. Indeed, many emerging fields lie at the intersection of disciplines, and participation in these discoveries and advances requires engineers equipped to engage in crossdisciplinary discovery.

The adoption of biogeotechnical methods in industry will take time. Often, the primary conventional ground improvement methods that compete with biogeochemical techniques are likely to be cement-based techniques, which the general public view largely as harmless/clean, in spite of the energyintensive, carbon-producing, manufacturing process for cementitious materials, which involves the quarrying of large volumes of raw materials and associated land impairment, coupled with their high $\mathrm{pH}$. Furthermore, there has often been public resistance to biotechnologies using exogenous organisms. Activities designed to raise awareness may be needed, as well as industry training, as field-scale applications of biogeotechnology become increasingly common.

\section{ACKNOWLEDGEMENTS}

The Second International Workshop on Bio-Soil Engineering and Interactions was funded in part by the United States 
National Science Foundation under Grant No. CMMI1110409. Any opinions, findings and conclusions or recommendations expressed in this material are those of the author(s), and do not necessarily reflect the views of the National Science Foundation.

\section{REFERENCES}

Al Qabany, A. (2011). Microbial carbonate precipitation in soils. Doctoral dissertation, University of Cambridge, UK.

Al Qabany, A. \& Soga, K. (2013). Effect of chemical treatment used in MICP on engineering properties of cemented soils. Géotechnique 63, No. 4, 331-339, http://dx.doi.org/10.1680/ geot.SIP13.P.022.

Al Qabany, A., Mortensen, B., Martinez, B., Soga, K. \& DeJong, J. (2011). Microbial carbonate precipitation: correlation of S-wave velocity with calcite precipitation. Proc. Geofrontiers 2011: Advances in Geotechnical Engineering, Dallas, TX, ASCE Geotechnical Special Publication 211, 3993-4001.

Al Qabany, A., Soga, K. \& Santamarina, J. C. (2012). Factors affecting efficiency of microbially induced calcite precipitation. ASCE J. Geotech. Geoenviron. Engng 138, No. 8, 992-1001.

Bachmeier, K. L., Williams, A.E., Warmington, J. R. \& Bang, S. S. (2002). Urease activity in microbiologically-induced calcite precipitation. J. Biotechnol. 93, No. 2, 171-181.

Baltzer, A., Cochonat, P. \& Piper, D. J. W. (1994). In situ geotechnical characterisation of sediments on the Nova Scotian Slope, eastern Canadian continental margin. Marine Geol. 120, No. 7, 291-308.

Banagan, B. L., Wertheim, B. M., Roth, M. J. S. \& Caslake, L. F. (2010). Microbial strengthening of loose sand. Lett. Appl. Microbiol. 51, No. 2, 138-142.

Bang, S. S., Lippert, J. J., Yerra, U., Mulukutla, S. \& Ramakrishnan, V. (2010). Microbial calcite, a bio-based smart nanomaterial in concrete remediation. Int. J. Smart Nano Mater. 1, No. 1, 28-39.

Bang, S., Min, S. H. \& Bang, S. S. (2011). Application of microbiologically induced soil stabilization technique for dust suppression. Int. J. Geo-Engng 3, No. 2, 27-37.

Barkouki, T., Martinez, B. C., Mortensen, B. M., Weathers, T. S., DeJong, J. T., Ginn, T. R., Spycher, N. F., Smith, R. W. \& Fujita, Y. (2011). Forward and inverse bio-geochemical modeling of microbially induced calcite precipitation in half-meter column experiments. Transp. Porous Media 90, No. 1, 23-39.

Barnes, R. S. K., Calow, P. \& Olive, P. J. W. (1988). The invertebrates: A new synthesis, 1st edn. Oxford, UK: Blackwell Scientific.

Baveye, P., Vandevivere, P., Hoyle, B. L., DeLeo, P. C. \& Sanchez de Lozada, D. (1998). Environmental impact and mechanisms of the biological clogging of saturated soils and aquifer materials. Crit. Rev. Environ. Sci. Technol. 28, No. 2, 123-191.

Benini, S., Rypniewski, W. R., Wilson, K. S., Miletti, S., Ciurli, S. \& Mangani, S. (1999). A new proposal for urease mechanism based on the crystal structures of the native and inhibited enzyme from Bacillus pasteurii: why urea hydrolysis costs two nickels. Structure 7, No. 2, 205-216.

Berg, R. D. (1996). The indigenous gastrointestinal microflora. Trends Microbiol. 4, No. 11, 430-435.

Blauw, M., Lambert, J. W. M. \& Latil, M. N. (2009). Biosealing: a method for in situ sealing of leakages. Proceedings of the International Symposium on Ground Improvement Technologies and Case Histories, ISGI'09, Singapore, 125-130.

Bonala, M. V. S. \& Reddi, L. N. (1998). Physicochemical and biological mechanisms of soil clogging: an overview. In Filtration and drainage in geotechnical/geoenvironmental engineering (eds L. N. Reddi and M. V. S. Bonalo), ASCE Geotechnical Special Publication 78, pp. 43-68. Reston, VA, USA: ASCE.

Burbank, M., Weaver, T., Green, T., Williams, B. \& Crawford, R. (2011). Precipitation of calcite by indigenous microorganisms to strengthen liquefiable soil. Geomicrobiol. J. 28, No. 4, 301-312.

Burbank, M., Weaver, T., Williams, B. \& Crawford, R. (2012a). Urease activity of ureolytic bacteria isolated from six soils in which calcite was precipitated by indigenous bacteria. Geomicrobiol. J. 29, No. 4, 389-395.

Burbank, M., Weaver, T., Lewis, R., Crawford, R. \& Williams, B. (2012b). Geotechnical tests of sands following bio-induced calcite precipitation catalyzed by indigenous bacteria. ASCE J. Geotech. Geoenviron. Engng, http://dx.doi.org/10.1061/(ASCE) GT.1943-5606.0000781.

Cabalar, A. F. \& Canakci, H. (2005). Ground improvement by bacteria. Proc. 3rd Biot Conference on Poromechanics, Norman, $O K, 707-712$.

Chaney, R. (1978). Saturation effects on the cyclic strength of sand. Proceedings of the ASCE Specialty Conference on Earthquake Engineering and Soil Dynamics, Pasadena, CA, pp. 342-359.

Cheng, L. \& Cord-Ruwisch, R. (2012). In situ soil cementation with ureolytic bacteria by surface percolation. Ecol. Engng 42, 64-72.

Chou, C.-W., Seagren, E. A., Aydilek, A. H. \& Maugel, T. K. (2008). Bacterially-induced calcite precipitation via ureolysis. Washington, DC, USA: ASM Microbe Library, Visual Media Briefs, http://www.microbelibrary.org/library/laboratorytest/3174-bacterially-induced-calcite-precipitation-via-ureolysis.

Chou, C.-W., Seagren, E. A., Aydilek, A. H. \& Lai, M. (2011). Biocalcification of sand through ureolysis. ASCE J. Geotech. Geoenviron. Engng 137, No. 12, 1179-1189.

Chu, J., Ivanov, V., Lee, M. F., Oh, X. M. \& He, J. (2009). Soil and waste treatment using biocement, Proceedings of the International Symposium on Ground Improvement Technologies and Case Histories, ISGI'09, Singapore, 165-170.

Chu, J., Ivanov, V., Naeimi, M., Li, B. \& Stabnikov, V. (2011). Development of microbial geotechnology in Singapore. Proc. Geofrontiers 2011: Advances in Geotechnical Engineering, Dallas, TX, ASCE Geotechnical Special Publication 211, 40704078.

Chu, J., Stabnikov, V. \& Ivanov, V. (2012). Microbially induced calcium carbonate precipitation on surface or in the bulk of soil. Geomicrobiol. J. 29, No. 6, 544-549.

Chu, J., Ivanov, V., Stabnikov, V. \& Li, B. (2013). Microbial method for construction of aquaculture pond in sand. Géotechnique, http://dx.doi.org/10.1680/geot.SIP13.P.007.

Ciurli, S., Benini, S., Rypniewski, W. R., Wilson, K. S., Miletti, S. \& Mangani, S. (1999). Structural properties of the nickel ions in urease: novel insights into the catalytic and inhibition mechanisms. Coordination Chem. Rev. 190-192, 331-355.

Cullimore, D. R. (1990). Microbes in civil engineering environments: biofilms and biofouling. In Microbiology in civil engineering (ed. P. Howsam), pp. 15-23. London, UK: E \& FN Spon.

Cunningham, A., Warwood, B., Sturman, P. et al. (1997). Biofilm processes in porous media. In The microbiology of the terrestrial deep subsurface (eds P. Amy and D. Haldeman), pp. 325-346. New York, NY, USA: Lewis Publishers.

Darcy, H. (1857). Recherches expérimentales relatives au mouvement de l'eau dans les tuyaux. Paris, France: Imprimerie Impériale (in French).

Day, J. L., Ramakrishnan, V. \& Bang, S. S. (2003). Microbiologically induced sealant for concrete crack remediation. Proc. 16th Engng Mech. Conf., Seattle, WA.

DeJong, J. T., Fritzges, M. B. \& Nüsslein, K. (2006). Microbial induced cementation to control sand response to undrained shear. ASCE J. Geotech. Geoenviron. Engng 132, No. 11, 1381-1392.

DeJong, J. T., Mortensen, B. \& Martinez, B. (2007). Bio-soils interdisciplinary science and engineering initiative, Final Report on Workshop, 84 pp. Arlingon, VA, USA: National Science Foundation.

DeJong, J. T., Martinez, B. C., Mortensen, B. M., Nelson, D. C., Waller, J. T., Weil, M. H., Ginn, T. R., Weathers, T., Barkouki, T., Fujita, Y., Redden, G., Hunt, C., Major, D. \& Tanyu, B. (2009). Upscaling of bio-mediated soil improvement. Proc. 17th Int. Conf. Soil Mech. Geotech. Engng, Alexandria, 2300-2303.

DeJong, J. T., Mortensen, M. B., Martinez, B. C. \& Nelson, D. C. (2010). Biomediated soil improvement. Ecol. Engng 36, No. 2, 197-210.

DeJong, J. T., Soga, K., Banwart, S. A., Whalley, W. R., Ginn, T., Nelson, D. C., Mortensen, B. M., Martinez, B. C. \& Barkouki, T. (2011). Soil engineering in vivo: harnessing natural biogeochemical systems for sustainable, multi-functional engineering solutions. J. R. Soc. Interface 8, No. 54, 1-15.

Ehlers, C. J., Chen, J., Roberts, H. H. \& Lee, Y. C. (2005). The origin of near-seafloor crust zones in deepwater. Proc. Int. Symp. 
on Frontiers in Offshore Geotechnics: ISFOG 2005, Perth, 927-934.

Esnault-Filet, A., Gadret, J. P., Loygue, M. \& Borel, S. (2012). Biocalcis and its application for the consolidation of sands. In Grouting and deep mixing 2012 (eds L. F. Johnsen, D. A. Bruce and M. J. Byle), Geotechnical Special Publication 288, vol. 2, pp. 1767-1780. Reston, VA, USA: ASCE.

Espinoza, D. \& Santamarina, J. C. (2010). Ant tunneling: a granular media perspective. Granular Matter 12, No. 6, 607-616.

Fauriel, S. (2012). Bio-chemo-hydro-mechanical modeling of soils in the framework of microbial induced calcite precipitation. $\mathrm{PhD}$ thesis, Ecole Polytechnique Fédérale de Lausanne, Switzerland.

Fauriel, S. \& Laloui, L. (2011a). A bio-hydro-mechanical model for propagation of biogrout in soils. Proc. Geo-Frontiers 2011: Advances in Geotechnical Engineering, Dallas, TX, ASCE Geotechnical Special Publication 211, 4041-4048.

Fauriel, S. \& Laloui, L. (2011b). Modelling of biogrout propagation in soils. Proc. 2nd Int. Symp. Computat. Geomech., Rhodes, $578-586$.

Fauriel, S. \& Laloui, L. (2012). A bio-chemo-hydro-mechanical model for microbially induced calcite precipitation in soils. Comput. Geotech. 46, 104-120.

Ferris, F. G., Stehmeier, L. G., Kantzas, A. \& Mourits, F. M. (1996). Bacteriogenic mineral plugging. J. Can. Petrol. Technol. 35, No. 8, 56-61.

Fujita, Y., Redden, G. D., Ingram, J. S., Cortez, M. M. \& Smith, R. W. (2004). Strontium incorporation into calcite generated by bacterial ureolysis. Geochim. Cosmochim. Acta 68, No. 15, $3261-3270$.

Fujita, Y., Taylor, J. L., Gresham, T. L. T., Delwiche, M. E., Colwell, F. S., McLing, T. L., Petzke, L. M. \& Smith, R. W. (2008). Stimulation of microbial urea hydrolysis in groundwater to enhance calcite precipitation. Environ. Sci. Technol. 42, No. $8,3025-3032$

Fujita, Y., Taylor, J. L., Wendt, L. M., Reed, D. W. \& Smith, R. W. (2010). Evaluating the potential of native ureolytic microbes to remediate a ${ }^{90} \mathrm{Sr}$ contaminated environment. Environ. Sci. Technol. 44, No. 19, 7652-7658

Gat, D., Tsesarsky, M. \& Shamir, D. (2011). Ureolytic $\mathrm{CaCO}_{3}$ precipitation in the presence of non-ureolytic competing bacteria. Proc. Geo-Frontiers 2011: Advances in Geotechnical Engineering, Dallas, TX, ASCE Geotechnical Special Publication $211,3966-3974$

Gingras, M. K., Pemberton, S. G., Dashtgard, S. \& Dafoe, L. (2008). How fast do marine invertebrates burrow? Palaeogeog. Palaeoclimatol. Palaeoecol. 270, No. 3-4, 280-286.

Gray, D. H. \& Sotir, R. B. (1996). Biotechnical and soil bioengineering stabilization. New York, NY, USA: John Wiley \& Sons.

Grupe, B., Becker, H. J. \& Oebius, H. U. (2001). Geotechnical and sedimentological investigations of deep-sea sediments from a manganese nodule field of the Peru Basin. Deep-Sea Res. Part II 48, No. 17-18, 3593-3608.

Hamdan, N., Kavazanjian, E. Jr \& Rittmann, B. E. (2011a). Sequestration of radionuclides and metal contaminants through microbially-induced carbonate precipitation. Proc. 14th Pan American Conf. Soil Mech. Geotech. Engng, Toronto, 5 pp.

Hamdan, N., Kavazanjian, E. Jr, Rittmann, B. E. \& Karatas, I. (2011b). Carbonate mineral precipitation for soil improvement through microbial denitrification. Proc. GeoFrontiers 2011: Advances in Geotechnical Engineering, Dallas, TX, ASCE Geotechnical Special Publication 211, 3925-3934.

Hamed, B. S. \& Belhadri, M. (2009). Rheological properties of biopolymer drilling fluids. J. Petrol. Sci. Engng 67, No. 3-4, $84-90$.

Hata, T., Tsukamoto, M., Mori, H., Kuwano, R. \& Gourc, J. P. (2011). Evaluation of multiple soil improvement techniques based on microbial functions. Proc. GeoFrontiers 2011: Advances in Geotechnical Engineering, Dallas, TX, ASCE Geotechnical Special Publication 211, 3945-3955.

He, J., Chu, J. \& Ivanov, V. (2013). Mitigation of liquefaction of saturated sand using biogas. Géotechnique, 63, No. 4, 267-275, http://dx.doi.org/10.1680/geot.SIP13.P.004.

Howsam, P. (ed.) (1990). Water wells, monitoring, maintenance and rehabilitation. London, UK: E \& FN Spon.

Inagaki, Y., Tsukamoto, M., Mori, H., Sasaki, T., Soga, K., Al Qabany, A. \& Hata, T. (2011a). The influence of injection conditions and soil types on soil improvement by microbial functions. Proc. GeoFrontiers 2011: Advances in Geotechnical Engineering, Dallas, TX, ASCE Geotechnical Special Publication 211, 4021-4030.

Inagaki, Y., Tsukamoto, M., Mori, H., Nakajiman, S., Sasaki, T. \& Kawasaki, S. (2011b). A centrifugal model test of microbial carbonate precipitation as liquefaction countermeasure. Jiban Kogaku Janaru 6, No. 2, 157-167.

Ishihara, K., Tsuchiya, H., Huang, Y. \& Kamada, K. (2001). Recent studies on liquefaction resistance of sand: effect of saturation. Proc. 4th Int. Conf. Recent Adv. Geotech. Earthquake Engng Soil Dynamics, San Diego, CA.

Ivanov, V. (2010). Microbial geotechniques. In Environmental microbiology for engineers, pp. 279-286. Boca Raton, FL, USA: CRC Press.

Ivanov, V. \& Chu, J. (2008). Applications of microorganisms to geotechnical engineering for bioclogging and biocementation of soil in situ. Rev. Environ. Sci. Biotechnol. 7, No. 2, 139-153.

James, G. A., Warwood, B. K., Hiebert, R. \& Cunningham, A. B. (2000). Microbial barriers to the spread of pollution. In Bioremediation (ed. J. J. Valdes), pp. 1-14. Amsterdam, the Netherlands: Kluwer Academic.

Jones, D. L., Nguyen, C. \& Finlay, R. D. (2009). Carbon flow in the rhizosphere: carbon trading at the soil-root interface. Plant and Soil 321, No. 1, 5-33.

Karatas, I., Kavazanjian, E. Jr \& Rittmann, B. E. (2008). Microbially induced precipitation of calcite using Pseudomonas denitrificans. Proc. 1st Int. Conf. Biogeotech. Engng, Delft (CDROM).

Kavazanjian, E. Jr \& Karatas, I. (2008). Microbiological improvement of the physical properties of soil. Proc. 6th Int. Conf. on Case Histories in Geotech. Engng, Rolla, MO (CD-ROM).

Kavazanjian, E. Jr, Iglesias, E. \& Karatas, I. (2009). Biopolymer soil stabilization for wind erosion control. Proc. 17th Int. Conf. Soil Mech. Geotech. Engng, Alexandria 2, 881-884.

Khachatoorian, R., Petrisor, I. G., Kwan, C.-C. \& Yen, T. F. (2003). Biopolymer plugging effect: laboratory-pressurized pumping flow studies. J. Petrol. Sci. Engng 38, No. 1-2, 13-21.

Kohnhauser, K. (2007). Introduction to geomicrobiology. Malden, MA, USA: Blackwell Publishing.

Kuo, M. Y. H. (2011). Deep ocean clay crusts: Behaviour and biological origin. Doctoral dissertation, University of Cambridge, UK

Kuo, M. Y. H. \& Bolton, M. D. (2011). Faecal pellets in deep marine soft clay crusts: implications for hot-oil pipeline design. Proc. 30th Int. Conf. on Ocean, Offshore and Artic Engineering, Rotterdam, 883-892.

Kuo, M. Y. H. \& Bolton, M. D. (2012). The nature and origin of deep ocean clay crust from the Gulf of Guinea. Géotechnique, http://dx.doi.org/10.1680/geot.10.P.012.

Kuo, M.Y.-H., Hill, A., Rattley, M. \& Bolton, M. D. (2010). New evidence for the origin and behaviour of deep ocean crusts. Proc. 2nd Int. Symp. on Frontiers in Offshore Geotechnics, Perth, 365-370.

Kuzyakov, Y. \& Domanski, G. (2000). Carbon input by plants into the soil: review. J. Plant Nutrition Soil Sci. 163, No. 4, 421431

Laloui, L. \& Fauriel, S. (2011). Biogrout propagation in soils. Proceedings of the international workshop on multiscale and multiphysics processes in geomechanics, Stanford, CT, pp. 77-80.

Lambert, J. W. M., Novakowski, K., Blauw, M., Latil, M. N., Knight, L. \& Bayona, L. (2010). Pamper bacteria, they will help us: application of biochemical mechanisms in geo-environmental engineering. In GeoFlorida 2010: Advances in Analysis, Modeling \& Design (eds D. O. Fratta, A. J. Puppala and B. Muhunthan), ASCE Geotechnical Special Publication 199, pp. 618-627. Reston, VA, USA: ASCE.

Legge, K. R., Scheurenburg, R., Clever, C., James, G. \& Claus, R. (1985). Investigation into apparent clogging of a geotextile recovered from Ergo Tailings Dam wall drain, Preliminary Report. Pretoria, Republic of South Africa: Department of Water Affairs and Forestry.

Li, M., Yang, Z., Guo, H. \& Cheng, X. (2011). Heavy metals removal by biomineralization of urea hydrolyzed bacteria isolated from soil. Proc. 1st Int. Conf. on Geomicrobial Ecotoxicology, Wuhan, 312-315. 
Manning, D. A. C. (2008). Biological enhancement of soil carbonate precipitation: passive removal of atmospheric $\mathrm{CO}_{2}$. Mineral. Mag. 72, No. 2, 639-649.

Martinez, B. C. (2012). Experimental and numerical upscaling of MICP for soil improvement. Doctoral dissertation, University of California, Davis, CA, USA.

Martinez, B. C. \& DeJong, J. T. (2009). Bio-mediated soil improvement: load transfer mechanisms at micro- and macro-scales. Proc. 2009 ASCE US-China Workshop on Ground Improvement Technologies, Orlando, FL, 242-251.

Martinez, B. C., Barkouki, T. H., DeJong, J. T. \& Ginn, T. R. (2011). Upscaling of microbial induced calcite precipitation in $0.5 \mathrm{~m}$ columns: experimental and modeling results. Proc. GeoFrontiers 2011: Advances in Geotechnical Engineering, Dallas, TX, ASCE Geotechnical Special Publication 211, 4049-4059.

Martinez, B. C., DeJong, J. T., Ginn, T. R., Mortensen, B. M., Barkouki, T. H., Hunt, C., Tanyu, B. \& Major, D. (2013). Experimental optimization of microbial induced carbonate precipitation for soil improvement. ASCE J. Geotech. Geoenviron. Engng (in press).

Meadows, A. \& Meadows, P. S. (1994). Bioturbation in deep-sea pacific sediments. J. Geol. Soc. 151, No. 2, 361-375.

Mitchell, A. C., Phillips, A. J., Hiebert, R., Gerlach, R., Spangler, L. H. \& Cunningham, A. B. (2009). Biofilm enhanced geological sequestration of supercritical $\mathrm{CO}_{2}$. Int. J. Greenhouse Gas Control 3, No. 1, pp. 90-99.

Mitchell, J. K. (1975). Fundamentals of soil behavior. New York, NY, USA: Wiley.

Mitchell, J. K. \& Santamarina, J. C. (2005). Biological considerations in geotechnical engineering. ASCE J. Geotech. Geoenviron. Engng 131, No. 10, 1222-1233.

Montoya, B. M. (2012). Bio-mediated soil improvement and the effect of cementation on the behavior, improvement, and performance of sand. Doctoral dissertation, University of California, Davis, CA, USA.

Montoya, B. M., Gerhard, R., DeJong, J., Weil, M., Martinez, B., Pederson, L. \& Wilson, D. (2012). Fabrication, operation, and health monitoring of bender elements for aggressive environments. Geotech. Test. J. 35, No. 5, 15 pp.

Montoya, B. M., DeJong, J. T. \& Boulanger, R. W. (2013). Dynamic response of liquefiable sand improved by microbial induced calcite precipitation. Géotechnique, 63, No. 4, 302-312, http://dx.doi.org/10.1680/geot.SIP13.P.019.

Mortensen, B. M. \& DeJong, J. T. (2011). Strength and stiffness of MICP treated sand subjected to various stress paths. Proc. GeoFrontiers 2011: Advances in Geotechnical Engineering, Dallas, TX, ASCE Geotechnical Special Publication 211, 40124020.

Mortensen, B. M., Haber, M., DeJong, J. T., Caslake, L. F. \& Nelson, D. C. (2011). Effects of environmental factors on microbial induced calcite precipitation. J. Appl. Microbiol. 111, No. 2, 338-349.

NRC (2006). Geological and geotechnical engineering in the new millennium: Opportunities for research and technological innovation. Washington, DC, USA: National Research Council.

Nugent, R. A., Zhang, G. \& Gambrell, R. P. (2010). The effect of exopolymers on the erosional resistance of cohesive sediments. Proc. 5th Int. Conf. on Scour and Erosion, San Francisco, CA, $162-171$

Phadnis, H. \& Santamarina, J. C. (2012). Bacteria in sediments: pore size effects. Géotechnique Lett. 1, 91-93.

Pietruszczk, S., Pande, G. N. \& Oulapour, M. (2003). A hypothesis for mitigation of risk of liquefaction. Géotechnique 53, No. 9, 833-838, http://dx.doi.org/10.1680/geot.2003.53.9.833.

Ramachandran, S. K., Ramakrishnan, V. \& Bang, S. S. (2001). Remediation of concrete using micro-organisms. ACI Mater. J. 98, No. 1, 3-9.

Ramakrishnan, V., Ramesh, K. P. \& Bang, S. S. (2001). Bacterial concrete. Proc. SPIE 4234, 168-176.

Rebata-Landa, V. \& Santamarina, J. C. (2006). Mechanical limits to microbial activity in deep sediments. Geochem. Geophys. Geosyst. 7, No. 11, 1-12.

Rebata-Landa, V. \& Santamarina, J. C. (2012). Mechanical effects of biogenic nitrogen gas bubbles in soils. ASCE J. Geotech. Geoenviron. Engng 138, No. 2, 128-137.

Renforth, P., Manning, D. A. C. \& Lopez-Capel, E. (2009).
Carbonate precipitation in artificial soils as a sink for atmospheric carbon dioxide. Appl. Geochem. 24, No. 9, 1757-1764.

Renforth, P., Edmondson, J., Leake, J. R., Gaston, K. J. \& Manning, D. A. C. (2011). Designing a carbon capture function into urban soils. Proc. ICE - Urban Design and Planning 164, No. 2, 121-128.

Roden, E. E., Leonardo, M. R. \& Ferris, F. G. (2002). Immobilization of strontium during iron biomineralization coupled to dissimilatory hydrous ferric oxide reduction. Geochim. Cosmochim. Acta 66, No. 16, 2823-2839.

Roscoe, K. H., Schofield, A. N. \& Wroth, C. P. (1958). On the yielding of soils. Géotechnique 8, No. 1, 22-53, http://dx.doi. org/10.1680/geot.1958.8.1.22.

Rusu, C., Cheng, X. \& Li, M. (2011). Biological clogging in Tangshan sand columns under salt water intrusion by Sporosarcina pasteurii. Adv. Mater. Res. 250-253, 2040-2046.

Sanderson, K. (2008). Waste concrete could help to lock up carbon. Nature, http://dx.doi.org/10.1038/news.2008.732.

Schofield, A. N. \& Wroth, C. P. (1968). Critical state soil mechanics. London, UK: McGraw-Hill.

Seagren, E. A. \& Aydilek, A. H. (2010). Biomediated geomechanical processes. In Environmental microbiology, 2nd edn (eds R. Mitchell and J.-D. Gu), pp. 319-348. Hoboken, NJ, USA: John Wiley \& Sons.

Seki, K., Miyazaki, T. \& Nakano, M. (1998). Effects of microorganisms on hydraulic conductivity decrease in infiltration. Eur. J. Soil Sci. 49, No. 2, 231-236.

Sherif, M. A., Ishibashi, I. \& Tsuchiya, C. (1977). Saturation effect on initial soil liquefaction. ASCE J. Geotech. Engng 103, No. 8, 914-917.

Sivavec, T., Krug, T., Berry-Spark, K. \& Focht, R. (2003). Performance monitoring of a permeable reactive barrier at the Somersworth, New Hampshire Landfill Superfund site. In Chlorinated solvent and DNAPL remediation (eds S. M. Henry and S. D. Warner), American Chemical Society, Symposium Series, Vol. 837, pp. 259-277. Washington, DC, USA: ACS Publications.

Slichter, C. S. (1905). Field measurements of the rate of movement of underground waters, USGS Water Supply and Irrigation Paper 140. Washington, DC, USA: Government Printing Office.

Stabnikov, V., Naeimi, M., Ivanov, V. \& Chu, J. (2011). Formation of water-impermeable crust on sand surface using biocement. Cement Concrete Res. 41, No. 11, 1143-1149.

Stal, L. J. (2010). Microphytobenthos as a biogeomorphological force in intertidal sediment stabilization. Ecol. Engng 36, No. 2, 236-245.

Stocks-Fischer, S., Galinat, J. K. \& Bang, S. S. (1999). Microbiological precipitation of $\mathrm{CaCO}_{3}$. Soil Biol. Biochem. 31, No. 11, $1563-1571$

Tagliaferri, F., Waller, J., Ando, E., Hall, S. A., Viggiani, G., Besuelle, P. \& DeJong, J. T. (2011). Observing strain localisation processes in bio-cemented sand using X-ray imaging. Granular Matter 13, No. 3, 247-250.

Talsma, T. \& van der Lelij, A. (1976). Infiltration and water movement in an in situ swelling soil during prolonged ponding. Aust. J. Soil Res. 14, No. 3, 337-349.

Taylor, D. (1948). Fundamentals of soil mechanics. New York, NY, USA: Wiley.

Taylor, L. L., Leake, J. R., Quirk, J., Hardy, K., Banwart, S. A. \& Beerling, D. J. (2009). Biological weathering and the long-term carbon cycle: integrating mycorrhizal evolution and function into the current paradigm. Geobiology 7, No. 2, 171-191.

Terzaghi, K. (1924). Erdbaumechanik. Vienna, Austria: Franz Deuticke (in German).

Terzaghi, K. (1955). Influence of geological factors on the engineering properties of sediments. Econ. Geol. 50, 557-618.

Tobler, D. J., Maclachlan, E. \& Phoenix, V. R. (2012). Microbially mediated plugging of porous media and the impact of different injection strategies. Ecol. Engng 42, 270-278.

Van Meurs, G., Van Der Zon, W., Lambert, J., Van Ree, D., Whiffin, V. \& Molendijk, W. (2006). The challenge to adapt soil properties. Proc. 5th ICEG: Environ. Geotechnics: Opportunities, Challenges and Responsibilities for Environ. Geotechnics, 2, 1192-1199.

Van Paassen, L. A. (2009). Biogrout, ground improvement by microbially induced carbonate precipitation. Doctoral dissertation, Department of Biotechnology, Delft University of Technology, the Netherlands. 
Van Paassen, L. A. (2011). Bio-mediated ground improvement: from laboratory experiment to pilot applications. Proc. GeoFrontiers 2011: Advances in Geotechnical Engineering, Dallas, TX, ASCE Geotechnical Special Publication 211, 40994108.

Van Paassen, L. A., Harkes, M. P., Van Zwieten, G. A., Van der Zon, W. H., Van der Star, W. R. L. \& Van Loosdrecht, M. C. M. (2009). Scale up of BioGrout: a biological ground reinforcement method. Proc. 17th Int. Conf. Soil Mech. Geotechn. Engng, Alexandria, 2328-2333.

Van Paassen, L. A., Daza, C. M., Staal, M., Sorokin, D. Y., van der Zon, W. \& van Loosdrecht, M. C. M. (2010a). Potential soil reinforcement by biological denitrification. Ecol. Engng 36, No. 2, $168-175$.

Van Paassen, L. A., Ghose, R., van der Linden, T. J. M., van der Star, W. R. L. \& van Loosdrecht, M. C. M. (2010b). Quantifying biomediated ground improvement by ureolysis: large-scale biogrout experiment. ASCE J. Geotech. Geoenviron. Engng 136, No. 12, 1721-1728.

Van Wijngaarden, W. K., Vermolen, F. J., van Meurs, G. A. M. \& Vuik, C. (2011). Modelling biogrout: a new ground improvement method based on microbial-induced carbonate precipitation. Transp. Porous Media 87, No. 2, 397-420.

Van Wijngaarden, W. K., Vermolen, F. J., van Meurs, G. A. M. \& Vuik, C. A. (2012). Mathematical model and analytical solution for the fixation of bacteria in biogrout. Transp. Porous Media 92, No. 3, 847-866.

Warthmann, R., van Lith, Y., Vasconcelos, C., McKenzie, J. A. \& Karpoff, A. M. (2000). Bacterially induced dolomite precipitation in anoxic culture experiments. Geology 28, No. 12, $1091-$ 1094.

Washbourne, C.-L., Renforth, P. \& Manning, D. A. C. (2012). Investigating carbonate formation in urban soils as a method for capture and storage of atmospheric carbon. Sci. Total Env. 431, $166-175$

Weaver, T., Burbank, M., Lewis, R., Lewis, A., Crawford, R. \& Williams, B. (2011). Bio-induced calcite, iron, and manganese precipitation for geotechnical engineering applications. Proc. GeoFrontiers 2011: Advances in Geotechnical Engineering, Dallas, TX, ASCE Geotechnical Special Publication 211, 39753983.

Weil, M. H., DeJong, J. T., Martinez, B. C. \& Mortensen, B. M. (2012). Seismic and resistivity measurements for real-time monitoring of microbially induced calcite precipitation in sand. ASTM Geotech. Test. J. 35, No. 2, GTJ103365.

Whiffin, V. S., Van Paassen, L. A. \& Harkes, M. P. (2007). Microbial carbonate precipitation as a soil improvement technique. Geomicrobiol. J. 24, No. 5, 417-423.

Whitman, W. B., Coleman, D. C. \& Wiebe, W. J. (1998). Prokaryotes: the unseen majority. Proc. Nat. Acad. Sci. 95, No. 12, $6578-6583$.

Woese, C. R., Kandler, O. \& Wheelis, M. L. (1990). Towards a natural system of organisms: proposal for the domains of Archaea, Bacteria, and Eucarya. Proc. Nat. Acad. Sci. 87, No. $12,4576-4579$.

Wu, J. G., Stahl, P. \& Zhang, R. (1997). Experimental study on the reduction of soil hydraulic conductivity by enhanced biomass growth. Soil Sci. 162, No. 10, 741-748.

Yang, Z., Cheng, X. \& Li, M. (2011). Engineering properties of MICP-bonded sandstones used for historical masonry building restoration. Proc. Geofrontiers 2011: Advances in Geotechnical Engineering, Dallas, TX, ASCE Geotechnical Special Publication 211, 4031-4040.

Yoshimi, Y., Tanaka, K. \& Tokimatsu, K. (1989). Liquefaction resistance of a partially saturated sand. Soils Found. 29, No. 3, $157-162$. 